\title{
Currency Crises and Monetary Policy in an Economy with Credit Constraints
}

\section{Citation}

Aghion, Philippe, Philippe Bacchetta, and Abhijit Banerjee. 2001. Currency crises and monetary policy in an economy with credit constraints. European Economic Review 45(7): 1121-1150.

\section{Published Version}

doi:10.1016/S0014-2921(00)00100-8

\section{Permanent link}

http://nrs.harvard.edu/urn-3:HUL.InstRepos:4554218

\section{Terms of Use}

This article was downloaded from Harvard University's DASH repository, and is made available under the terms and conditions applicable to Other Posted Material, as set forth at http:// nrs.harvard.edu/urn-3:HUL.InstRepos:dash.current.terms-of-use\#LAA

\section{Share Your Story}

The Harvard community has made this article openly available.

Please share how this access benefits you. Submit a story.

Accessibility 


\title{
Currency Crises and Monetary Policy in an Economy with Credit Constraints ${ }^{1}$
}

\author{
Philippe Aghion \\ University College London, EBRD, and CEPR \\ Philippe Bacchetta \\ Study Center Gerzensee, \\ University of Lausanne, and CEPR \\ Abhijit Banerjee \\ Massachusetts Institute of Technology
}

June 2000

Third draft. Comments welcome.

\footnotetext{
${ }^{1}$ We would like to thank Beatriz Armendariz, Olivier Blanchard, Daniel Cohen, Giancarlo Corsetti, Allan Drazen, Linda Goldberg, Roger Guesnerie, Pentti Haaparanta, Ricardo Hausman, Olivier Jeanne, Robert King, Paul Krugman, Philip Lane, Jacques Melitz, Jeffrey Nilsen, Paolo Pesenti, Hélène Rey, and seminar paticipants at ISOM, ESSIM, Santiago de Compostela, Gerzensee, Basel, Munich, and Vienna for useful discussions and comments.
} 


\begin{abstract}
This paper presents a simple model of currency crises which is driven by the interplay between the credit constraints of private domestic firms and the existence of nominal price rigidities. The possibility of multiple equilibria, including a 'currency crisis' equilibrium with low output and a depreciated domestic currency, results from the following mechanism: if nominal prices are 'sticky', a currency depreciation leads to an increase in the foreign currency debt repayment obligations of firms, and thus to a fall in their profits; this reduces firms' borrowing capacity and therefore investment and output in a credit-constrained economy, which in turn reduces the demand for the domestic currency and leads to a depreciation. We examine the impact of various shocks, including productivity, fiscal, or expectiational shocks. We then analyze the optimal monetary policy to prevent or solve currency crises. We also argue that currency crises can occur both under fixed and flexible exchange rate regimes as the primary source of crises is the deteriorating balance sheet of private firms.
\end{abstract}




\section{Introduction}

Currency crises have been traditionally viewed as retribution for governments that have mismanaged the economy and/or lack credibility: both the socalled first generation models and the more recent second generation models broadly answer to this description. However, the recent crises in East and Southeast Asia have lead to a wide-spread questioning of this view. ${ }^{1}$ It is observed that most of the crisis economies enjoyed government surpluses and increasing foreign exchange reserves (unlike what the first generation models would suggest) as well as low unemployment and booming exports (unlike in most of the second generation models). Of course there are other forms of government failure. In the case of the East and Southeast Asian countries there is some evidence that the financial sector in these countries was not very well-regulated. Without denying that this was an important element of the crisis, there is reason to doubt that it is the whole story: first because the lack of transparency in the financial sector of these countries was already well-known among market participants and second because these economies have now recovered and face interest rates not significantly higher than before the crisis, without any major overhaul of the financial sector.

It is therefore not surprising that over the last two or three years, a third generation of models of financial crises has begun to emerge. ${ }^{2}$ These models have in common the idea that the crisis should be seen as a result of a shock that was amplified by what Bernanke, Gertler, and Gilchrist (1999) have called a financial accelerator mechanism. In some of these models (Aghion, Bacchetta, and Banerjee, 1999a,b) there is a real shock that gets amplified while in others (Krugman,1999a, Chang and Velasco, 1999) there are multiple equilibria with the crisis brought on by a pure shift in expectations. The basic story is similar: a real currency depreciation can have a large effect on output if it affects the credit access of some subset of agents; ${ }^{3}$ moreover this effect on output may in turn affect the exchange rate, further amplifying the shock and causing it to persist.

\footnotetext{
${ }^{1}$ For example, see Krugman (1999a), Furman and Stiglitz (1998), Radelet and Sachs (1998).

${ }^{2}$ See Aghion, Bacchetta, and Banerjee (1999a, b), Krugman (1999a), Chang and Velasco (1999).

${ }^{3}$ In Chang and Velasco (1999) the effect on the borrowing capacity of the firm sector is indirect-it comes from a fall in the lending capacity of the banking sector. Therefore their model is not strictly a financial accelerator model.
} 
The present paper is a contribution to this line of research. It differs from the previous papers in that it is an explicitly dynamic monetary model with nominal rigidities playing an important role. ${ }^{4}$ This approach allows us to tell a very simple story of currency crises: if nominal prices are rigid in the short run, a currency depreciation leads to an increase in the foreign currency debt repayment obligations of the firms, and consequently a fall in profits. ${ }^{5}$ Since lower profits reduce net worth, it may result in less investment and lower output in the next period. This, in turn, brings a fall in the demand for money, and thus a currency depreciation. But arbitrage in the foreign exchange market then implies that the currency must depreciate in the current period as well. In other words, if people believe that the currency will depreciate, it may indeed depreciate. Multiple short run equilibria in the market for foreign exchange are thus possible. A currency crisis occurs either when expectations change or when a real shock shifts the economy to the "bad" equilibrium.

This story of currency crises has the significant advantage that it is based on two well-known facts: first, the countries most likely to go into a crisis were those in which firms held a lot of foreign currency denominated debt. For example, Figure 1 shows the ratio of claims to liabilities with respect to BIS banks; since these transactions are basically in foreign currency, this ratio is a measure of aggregate foreign currency exposure. ${ }^{6}$ It is striking that all the countries that had a ratio higher than 1.5 have experienced a serious crisis in the 1990s. The second fact is that there are substantial and persistent deviations from purchasing power parity following an exchange rate shock. ${ }^{7}$ By contrast Banerjee (1999) argues that the models such as

\footnotetext{
${ }^{4}$ Aghion, Bacchetta, and Banerjee (2000a) contains a precursor of the model in this paper. Krugman (1999b) presents an elegant simplification of the model in Aghion, Bacchetta, and Banerjee (2000a).

${ }^{5}$ The damaging impact of foreign currency debt is often mentioned in the context of currency crises. See, for example, Cooper (1971), Calvo (1998) and Mishkin (1996, 1999). While the role of foreign currency public debt has received some attention in the theoretical literature on crises (e.g. Bohn, 1990, Obstfeld, 1994, Falcetti and Missale, 1999), the impact of private foreign currency debt has hardly been analyzed (see, however, Jeanne, 2000a).

${ }^{6}$ Debt to banks from BIS countries is often used as a measure of foreign currency debt, as no good measure is available. Corsetti, Pesenti, and Roubini (1998) present the same ratio as in Figure 1 for Asian countries.

${ }^{7}$ After a currency crisis, deviations from PPP, or from the law of one price, are also large for tradeable goods. This evidence speaks even more in favor of price stickiness than
} 
Krugman (1999a), Chang and Velasco (1999) and our own previous work, require large changes in the relative price of tradeables and non-tradeables, as well as specific assumptions about the role of tradeable and non-tradeable goods in the economy. ${ }^{8}$

This credit-based approach to currency crises is consistent with numerous features observed in recent crises and left unexplained by the previous literature. For example, countries with less developed financial systems are more likely to experience an output decline during a crisis. ${ }^{9}$ Second, a currency crisis can also happen under a flexible exchange rate or without any significant decline in foreign exchange reserves. Third, crises may occur even in countries where governments face low unemployment and/or conduct sound fiscal policies and do not resort much on seigniorage.

Obviously public policy variables such as fiscal deficits can play an important role in facilitating the occurrence of a currency crisis, as stressed by the existing literature on the subject. However, in contrast to first- and secondgeneration models, in the world described in this paper a deterioration of fiscal balances will lead to a crisis mainly through its impact on private firms' balance sheets rather than through simple money demand adjustments as in the previous models. ${ }^{10}$ Moreover, the presence of public sector debt may exacerbate the problems of private sector debt, especially if a large fraction of public sector debt is in foreign currency. This result is in sharp contrast with the previous literature that finds that foreign currency (public) debt has a stabilizing role.

Another advantage of our monetary model is that it lends itself very naturally to the analysis of monetary policy. There has been an important debate on the stance of monetary policy in the context of currency crises; in particular, the previous literature does not provide much guidance in the debate between those who emphasize past government failure and advocate

the systematic studies of PPP deviations for major currencies, such as Engel (1993).

${ }^{8}$ In Chang and Velasco (1999) it is important that most of the borrowing is in the tradeable sector but the lending capacity of bank depends on the valuation of non-tradeable assets. Moreover non-tradeables are not used in the production of tradeables. By contrast, in Aghion, Bacchetta, and Banerjee (1999a, b) the fact that non-tradeables are used in the production of tradeables is absolutely key.

${ }^{9}$ It is indeed striking that several countries that experienced a large depreciation in the ERM crisis in 92-93 had a relatively good output performance; while others, like Finland, and countries that suffered from the Mexican and Asian crises faced serious recessions.

${ }^{10}$ Surveys of the currency crises literature, include Garber and Svensson (1995), Obstfeld and Rogoff (1996), and Flood and Marion (1998). 
monetary tightening, ${ }^{11}$ and those who blame shifts in expectations and bad luck (the multiple equilibrium view) and consequently support a more lenient approach to monetary policy. ${ }^{12}$ In our basic model in which the credit multiplier is either constant or dependant upon the real interest rate and price stickiness remains limited, a restrictive monetary policy is the optimal response to the risk of a currency crisis. However, this conclusion may cease to hold when credit supply is affected by the nominal interest rate and/or price stickiness is sufficiently persistent compared to the duration of debt contracts.

The rest of the paper is organized as follows. Section 2 lays out the basic model. Section 3 shows that this model naturally gives itself to graphical analysis. Using this graphical apparatus we examine the occurrence of currency crises and demonstrate the possibility of multiple equilibria. Section 4 introduces the public sector into the model, first by analyzing explicitly a fixed exchange rate system and second by introducing fiscal variables. In Section 5 we analyze the impact of monetary policy and we conclude in Section 6.

\section{The Basic Model}

\subsection{General Framework}

We consider an infinite-horizon small open economy monetary model where goods prices are determined at the beginning of each period and remain fixed for the entire period. ${ }^{13}$ There is a single tradeable good and purchasing power parity (PPP) holds ex ante, i.e., $P_{t}=E_{t}^{e}$ for each $t$, where $P_{t}$ is the domestic price, $E_{t}^{e}$ is the expected nominal exchange rate (the price of foreign currency in terms of domestic currency) at the beginning of period $t$, and the foreign price is constant and equal to one.

A key ingredient of our model will be a shock in period one that occurs after the price in that period has been set. This shock may be real — such

\footnotetext{
${ }^{11}$ This view has been consistently advocated by the IMF. In particular, Stanley Fischer argues that "those who criticize temporary high interest rates fail to see that further depreciation caused by lower rates would have raised the burden of dollar-denominated debts".

${ }^{12}$ See for example Radelet and Sachs (1998) and Furman and Stiglitz (1998).

${ }^{13}$ The assumption that prices are preset for one period is commonly made in monetary models of an open economy, following Obstfeld and Rogoff (1995).
} 
as a change in productivity or competitiveness or the risk perceptions of bondholders at home or abroad. Or it may be a pure shift in expectations - as is well-known, in a world of multiple equilibria, such shifts can have real effects. ${ }^{14}$ The shock causes a deviation from purchasing power parity: since prices cannot move during period one, the nominal exchange rate has to move to absorb the shock. ${ }^{15}$ These deviations will play a crucial role in the analysis.

Finally we assume that credit markets are imperfect. Specifically, we assume that the economy is populated by identical entrepreneurs who face a credit limit which is a fixed multiple of their current real wealth $w_{t}$, in the spirit of Bernanke and Gertler (1989). Entrepreneurs' wealth is thus the fundamental variable that determines investment and output.

In all other respects the model is quite standard: output is produced using capital and the production function $y_{t}=f\left(k_{t}\right)$ has the standard concave shape. There is full capital mobility and uncovered interest parity holds. The exchange rate can be either floating or fixed, even though the fixed exchange rate case is only explicitly analyzed in Section 4 . Consumers need money for their transactions and there is a central bank that can alter interest rates or the exchange rate by affecting money supply.

The timing of events can be summarized as follows. In the first period, the price $P_{1}$ is preset and firms invest. Then, an unanticipated shock occurs followed by a monetary adjustment which determines both the nominal interest rate $i_{1}$ to be paid at the end of the second period (interest rates are always set one period ahead) and the nominal exchange rate $E_{1}$ (when the latter is not maintained fixed). Subsequently, period 1's output and profits are generated and firms' debts are repaid. Finally, a fraction $(1-\alpha)$ of net retained earnings after debt repayment, namely $w_{2}$, is saved for investment in period 2. Periods after period 1 are identical in all respects except in that after period 2, no further shock occurs and the economy converges to

\footnotetext{
${ }^{14}$ For most of the paper we assume that the shock is wholly unanticipated and is not taken into account by the domestic market when setting the date- 1 price. This assumption is commonly made by the existing models of open monetary macroeconomics (see again Obstfeld and Rogoff, 1995). It can be shown, however, that our results hold when the distribution of expectational shocks is taken into account ex ante.

${ }^{15}$ Producers set prices in domestic currency by taking the foreign price (adjusted by the expected exchange rate) as given. In contrast to some recent models in the so-called "New Open Economy Macroeconomics", we implicitly assume perfect competition on the product market.
} 
its steady state.

The remaining part of this section, first, describes in detail the monetary side of the economy and, second, analyzes the entrepreneurs' borrowing and production decisions.

\subsection{The Monetary Sector}

The interaction between consumers, foreign investors, and the central bank gives us both a money market equilibrium condition (i.e., an LM curve) and an interest parity condition (i.e., an IP curve). Since both types of conditions are standard in open economy macroeconomics, we shall not expand on their microfoundations. ${ }^{16}$ Arbitrage by investors between domestic and foreign currency bonds in a world with perfect capital mobility yields the following interest parity (IP) condition:

$$
1+i_{t}=\left(1+i^{*}\right) \frac{E_{t+1}^{e}}{E_{t}}
$$

where $i^{*}$ is the foreign interest rate which we assume to be constant over time.

In addition, consumers have a standard real money demand function $m_{t}^{d}=m^{d}\left(y_{t}, i_{t}\right)$. The function $m^{d}$ has the usual properties of being increasing in $y_{t}$ and decreasing in $i_{t}{ }^{17}$ furthermore, we assume: $m^{d}\left(0, i_{t}\right)>0 .{ }^{18}$ Thus, at any date $t$, money market equilibrium can be expressed by the $(\mathrm{LM})_{t}$ equation:

$$
M_{t}^{S}=P_{t} \cdot m^{d}\left(y_{t}, i_{t}\right)
$$

where $M_{t}^{S}$ is the nominal money supply at date $t$. Let $z_{t}$ denote the rate of nominal money supply growth between periods $t-1$ and $t$, so that: $M_{t}^{S}=$ $\left(1+z_{t}\right) M_{t-1}^{S}$. Computing the growth rate of equation (2), we can determine the evolution of the inflation rate $\pi_{t}$ :

$$
1+\pi_{t}=\left(1+z_{t}\right) \frac{m_{t-1}^{d}}{m_{t}^{d}}
$$

\footnotetext{
${ }^{16}$ For example, see Krugman and Obstfeld (2000) and Blanchard (1996) for pedagogical presentations of the LM and IP relationships.

${ }^{17}$ This follows from consumers' arbitrage between holding money for transaction purposes and holding (domestic) bonds that yield interest rate $i_{t}$.

${ }^{18}$ This last assumption is needed in our context since output only depends on past profits and therefore can be equal to zero. It can be dropped in a more general context, for example when we introduce a competitiveness effect (see Section 3 below).
} 
Equation (3) holds for all periods without shocks, in our analysis for $t \geq 2$. In period one, since price $P_{1}$ is preset, it is the interest rate $i_{1}$ that adjusts to equilibrate the money market. Thus, equation (2) yields:

$$
i_{1}=\phi\left(M_{1}^{S}, y_{1}\right)
$$

where $\phi$ is the inverse of the $m^{d}$ function with respect to $i$. The relationship between $i_{1}$ and $M_{1}^{S}$ is unambiguously negative due to the standard liquidity effect. Thus, either of the two variables can be used to discuss the effects of monetary policy in period one.

\subsection{Output and Entrepreneurs' Debt}

Our analysis in this subsection rests on two basic assumptions on the real side of the economy. First, due to the existence of credit constraints, at date $t$ entrepreneurs can at most borrow an amount $d_{t}$ proportional to their cash flow $w_{t}: d_{t} \leq \mu_{t} w_{t}$. They can borrow either in domestic currency at interest rate $i_{t-1}$ or in foreign currency at $i^{*}$. Throughout most of the paper, we shall take the credit multiplier to be constant, i.e., $\mu_{t}=\mu .{ }^{19}$ This assumption will be relaxed in Section 5 where we allow the credit multiplier to depend upon the real and/or nominal interest rates.

Since capital is the only production input and fully depreciates within one period, entrepreneurs' capital stock at the beginning of each period $t$ is: $k_{t}=$ $w_{t}+d_{t}$. Thus, current output becomes a function of current entrepreneurs' wealth whenever the credit constraint is binding, namely:

$$
y_{t}=f\left((1+\mu) w_{t}\right) .
$$

When the constraint is not binding $\left(d_{t}<\mu w_{t}\right)$, the levels of borrowing and output are simply given by the standard first-order condition: $f^{\prime}\left(k_{t}\right)=1+i^{*}$.

The second assumption relates to the choice that domestic investors face between domestic and foreign currency debt. This is an important unresolved issue in the literature and we do not attempt to solve it here. ${ }^{20}$ We simply

\footnotetext{
${ }^{19}$ See for example Aghion, Banerjee, and Picketty (1999) for a specification of credit monitoring costs which produces a constant multiplier.

${ }^{20}$ We explore this issue in Aghion, Bacchetta, and Banerjee (2000b). See also Jeanne (2000a) who shows that foreign currency debt may serve as a commitment device and may lower the cost of debt. Burnside, Eichenbaum, and Rebelo (2000) show that foreign currency debt is also preferred when government subsidies to banks are contingent on a devaluation.
} 
assume that in period $t$, the quantity of domestic currency debt is $d_{t}^{c}{ }^{21}$ This assumption is easy to justify in the case considered in this paper, where the crisis results from an unanticipated shock. In this case, the borrowers do not take account of the potential for a crisis when they are making their decision about the currency composition of debt and as a result, even very small advantages with respect to transaction costs or currency risk can lead to a lot of foreign currency borrowing.

When crises are anticipated, the key issue is whether the endogeneity of currency exposure would eliminate the possibility of a crisis. Note that when the borrower chooses the currency composition of his own debt, he takes as given the composition of debt in the rest of the economy - he will not deviate from his privately optimal choice of currency composition to prevent a crisis. He may have private reasons for preferring domestic currency debt if there is some chance of a crisis, especially if default is costly for him. However, given that he cannot prevent the crisis by making this choice, moving to domestic debt simply shifts the risk on to the lender, who will accept it only if the price the borrower pays for the insurance (in terms of foregone benefits from holding foreign currency debt as well as the cost of compensating the lender for the extra risk he bears) is worthwhile; this would only be the case if a crisis were sufficiently likely. It follows that if all the other borrowers were to choose levels of $d_{t}^{c}$ that are such that no crisis is possible, an individual borrower would simply choose the level of $d_{t}^{c}$ that is optimal for him absent the possibility of a crisis. If this preferred level of foreign currency debt happens to be higher than the minimum needed to make a crisis possible, the only equilibrium value of $d_{t}^{c}$ is one where there will sometime be a crisis. Note that this reasoning is valid independently of the reason for which borrowers hold foreign currency debt.

Given the currency composition of domestic entrepreneurs' debt, we can now express their aggregate nominal profits net of debt repayments at the end of any period $t$, namely:

$$
\Pi_{t}=P_{t} y_{t}-\left(1+i_{t-1}\right) P_{t-1} d_{t}^{c}-\left(1+i^{*}\right) \frac{E_{t}}{E_{t-1}} P_{t-1}\left(d_{t}-d_{t}^{c}\right)
$$

Whenever profits are positive, entrepreneurs retain a proportion $(1-\alpha)$ of profits and use them to finance their future investment (a proportion $\alpha$ of

\footnotetext{
${ }^{21}$ The main conclusions and results in this paper remain unchanged if the fraction of domestic versus foreign currency debt, instead of the amount of domestic currency debt, is taken as a basic parameter of the model (see Bacchetta (2000)).
} 
profits is distributed and/or consumed). Total net wealth available for the next production period $t+1$ is thus equal either to zero, when net profits at date $t$ are negative, or to:

$$
w_{t+1}=(1-\alpha) \frac{\Pi_{t}}{P_{t}}
$$

It follows that second period output $y_{2}$, which is a function of the wealth $w_{2}$ available at the beginning of period 2 , is given by:

$$
y_{2}=f\left((1+\mu)(1-\alpha)\left\{y_{1}-\left(1+r_{0}\right) d_{1}^{c}-\left(1+i^{*}\right) \frac{E_{1}}{P_{1}}\left(d_{1}-d_{1}^{c}\right)\right\}\right)
$$

where $r_{0}$ is the real interest rate defined as $1+r_{t}=\left(1+i_{t}\right) P_{t} / P_{t+1}$ and $0<$ $y_{2}<\widetilde{y}$. Equation (5) clearly shows that output would react negatively to an increase in the debt burden induced by a currency depreciation, that is by an increase in $E_{1}$. Note that changes in the nominal interest rate $i_{1}$ do not affect the debt burden in period 1 and output in period 2 . The reason is simply that $i_{1}$ is the interest rate applying to the second period.

However, $i_{1}$ will affect the cost of domestic currency debt and therefore the debt burden in period 2 positively, and therefore the output in period 3 negatively. More formally, we have:

$$
y_{3}=f\left((1+\mu)(1-\alpha)\left\{y_{2}-\left(1+i_{1}\right) \frac{P_{1}}{P_{2}} d_{2}^{c}-\left(1+i^{*}\right) \frac{E_{2}}{E_{1}} \frac{P_{1}}{P_{2}}\left(d_{2}-d_{2}^{c}\right)\right\}\right)
$$

In any period $t \geq 3$, the PPP condition continues to hold but in addition the discrepancy between $E_{1}$ and $P_{1}$ no longer affects the total debt burden of entrepreneurs, i.e., domestic and foreign currency debt become fully equivalent. Hence, for $t \geq 3$ output $y_{t+1}$ is simply given by:

$$
y_{t+1}=f\left[(1+\mu)(1-\alpha)\left\{y_{t}-\left(1+i^{*}\right) d_{t}\right\}\right] \text {. }
$$

The model is now fully laid out. Equilibrium in this model is defined as a sequence of prices $\left(P_{t}\right)$, exchange rates $\left(E_{t}\right)$ and output levels $\left(y_{t}\right)$, which for a given monetary policy in period 1 satisfy the above equations $(1),(2),(3)$, (5) and (7) for all $t$. The dynamics of aggregate output $y_{t}$ for $t>2$, are easy to compute and can be simulated numerically. However, a diagrammatic presentation offers more insight into the nature of the equilibrium and is presented in the following section. 


\section{The Occurrence of Currency Crises}

In this section we focus on the first two periods of production and lending $t=1,2$, so that we can analyze the mechanics of the model using simple graphical representation. In particular, we describe the mechanism leading to multiple expectational equilibria and the subsequent possibility of a currency crisis. Finally, we examine how the results in this section are modified once we introduce a competitiveness effect.

\subsection{A Graphical Representation of the Model}

Throughout the remaining part of the paper, we concentrate on the case where the nominal interest rate in period $2, i_{2}$, is maintained constant by monetary policy in subsequent periods. ${ }^{22}$ In other words, we implicitly assume that the government follows an interest rate targeting or inflation rate targeting ( $\pi_{3}$ is fixed) policy. ${ }^{23}$ In Aghion, Bacchetta, Banerjee (2000b), we show that this assumption can be relaxed without significantly altering the results. ${ }^{24}$ Taking $i_{2}$ as given, the mechanics of the model will now be shown to be fully described by two curves in the $\left(E_{1}, y_{2}\right)$ space: an IPLM("Interest-Parity-LM") curve which describes how future (i.e., period-2) expected output $y_{2}$ influences the current (i.e., period-1) exchange rate, $E_{1}$, and a W- (or "Wealth"-) curve which describes the period-2 output response of credit-constrained entrepreneurs, $y_{2}$, to variations in the (end of ) period-1

\footnotetext{
${ }^{22}$ Jeanne (2000b) presents first and second generation models using a related two-period approach.

${ }^{23}$ Indeed, as shown above, we have: $1+i_{2}=\left(1+i^{*}\right)\left(1+\pi_{3}\right)$.

${ }^{24}$ For example, suppose that the government targets the rate of money growth $z$ instead, and for simplicity let us take the inflation rate in period $4, \pi_{4}$, as given; then using the fact that:

$$
1+\pi_{3}=\left(1+z_{3}\right) \frac{m_{2}^{d}\left(y_{2}, i_{2}\right)}{m_{3}^{d}\left(y_{3}, i_{3}\right)}
$$
}

and:

$$
1+i_{3}=\left(1+i^{*}\right)\left(1+\pi_{4}\right)
$$

we can endogeneize $i_{2}$ as a function of $y_{2}$ and $y_{3}$, increasing in $y_{2}$ and decreasing in $y_{3}$. In particular, by decreasing $y_{3}$, a tight monetary policy, i.e., an increase in the nominal interest rate $i_{1}$, in period 1 , will induce an increase in $i_{2}$. This in turn will tend to counteract, but only partly so, the positive effects of such a policy on the demand for the domestic currency and therefore on its value relative to the foreign currency (see AghionBacchetta-Banerjee (2000b)). 
exchange rate.

The IPLM curve is completely standard: it is simply obtained by combining the interest parity condition (1) with the LM equation (2) at $t=2$ (i.e., $\mathrm{LM}_{2}$ ) in which the period- 2 nominal interest rate $i_{2}$ is taken as given. Using the PPP assumption $P_{2}=E_{2}^{e}=E_{2}$ (the latter equality follows from the absence of shock in period 2) we get:

$$
E_{1}=\frac{1+i^{*}}{1+i_{1}} \cdot \frac{M_{2}^{S}}{m^{d}\left(y_{2}, i_{2}\right)}
$$

which provides a negative relationship between $E_{1}$ and $y_{2}$. This relationship is shown in Figure 2 as the IPLM curve. ${ }^{25}$ It is easy to see why the IPLM curve slopes down: an increase in (expected) future output $y_{2}$ increases the demand for money (i.e., for domestic currency) in period 2, which in turn will naturally generate a nominal currency appreciation in that period, i.e., a reduction in $E_{2}=P_{2}$. The anticipation of an currency appreciation 'tomorrow' (i.e., in period 2) increases the attractiveness of holding domestic currency today, and therefore induces a currency appreciation today, i.e., a reduction in $E_{1}$.

The IPLM curve can be shifted by changes in monetary policy at date $t=1,2$. For example, a tight monetary policy which reduces $M_{1}^{S}$ or increases $i_{1}$ (from (4)), results in a nominal currency appreciation, i.e., a reduction in $E_{1}$ for any given $y_{2}$. Therefore, a tight monetary policy shifts the IPLM curve upwards. The same occurs with a reduction in $M_{2}^{S}$. These effects are standard: for a given output level, the domestic currency appreciates after a monetary compression in the first period due to a shortage of liquidity and it depreciates after a monetary compression in the second period due to an expected reduction in inflation. Finally, increases in $i_{2}$ also shift the IPLM upwards.

The slope of the IPLM curve also depends on how mobile capital is and the extent of substitutability between domestic and foreign currency assets. We have so far assumed perfect mobility and perfect substitutability. Relaxing the first assumption, for example by introducing the possibility of capital controls, will weaken the relationship between $i_{1}$ and $E_{1}$. In the extreme case of no capital mobility, the IPLM curve disappears. Relaxing the second assumption introduces a foreign exchange risk premium, a case which

\footnotetext{
${ }^{25}$ Note that our curve differs slightly from the AA curve in Krugman and Obstfeld (2000), which relates $E_{1}$ to $Y_{1}$ instead of $Y_{2}$, and keeps all period 2 variables constant.
} 
is examined in Section 3. In that case what matters is what determines the premium.

While the IPLM curve is directly drawn from standard macroeconomic textbooks and holds even when credit markets are perfect, the W-curve captures the effect of imperfect credit markets. It is given by equation (5):

$$
y_{2}=f\left((1+\mu)(1-\alpha)\left\{y_{1}-\left(1+r_{0}\right) d_{1}^{c}-\left(1+i^{*}\right) \frac{E_{1}}{P_{1}}\left(d_{1}-d_{1}^{c}\right)\right\}\right) .
$$

At the beginning of period 1, all variables on the right-hand side of (9) are fixed except for $E_{1}\left(P_{1}\right.$ is given since prices are preset and fixed for the entire period 1). ${ }^{26}$ Changes in $E_{1}$ (with $P_{1}$ fixed) have a negative effect on $y_{2}$ : an increase in $E_{1}$ (a depreciation) reduces first period profits $\Pi_{1}$ through an increase in the foreign currency debt burden of domestic entrepreneurs. Representing equation (9) (along with the constraint $0<y_{2}$ ) graphically in the $\left(E_{1}, y_{2}\right)$ space gives us our $\mathrm{W}$ - curve as depicted in Figure 3 . The $\mathrm{W}$ curve includes an upward segment of the vertical axis when $E_{1}$ is such that equation (9) yields $y_{2} \leq 0$. In the following subsection, we show that under certain conditions the economy summarized by this graphical representation, has two "locally stable" equilibria and argues that the process of switching from the "good" equilibrium to the "bad" equilibrium can be naturally interpreted as a currency crisis.

To conclude this section let us briefly compare our model with a standard open macro model. Such a model would include the same kind of IPLM relationship between expected output and the current nominal exchange rate, but on the other hand: (i) our downward-sloping W curve would be replaced by an upward-sloping IS curve (with entrepreneurs' output decisions being constrained by aggregate demand instead of being constrained by current wealth); (ii) our price rigidity assumption would be replaced by some kind of a Phillips curve that would determine the rate of price adjustment as a function of the other variables of the model. The fact that the $\mathrm{W}$ curve slopes down is of course key to our analysis. Consequences of relaxing this assumption will be discussed later. The value of making specific assumptions about price rigidity rather than adopting an omnibus Phillips curve approach

\footnotetext{
${ }^{26}$ The nominal exchange rate $E_{1}$, however, has an impact on $y_{2}$ when there are deviations from PPP in period 1, i.e., if there is an unanticipated shock to fundamentals or to expectations such that $E_{1} \neq P_{1}$. The $\mathrm{W}$-curve has in common with the Phillips curve that it is vertical in the absence of unanticipated shocks.
} 
is that it makes clear why different degrees of rigidity can have very different implications for the optimal monetary response to currency crises.

\subsection{Equilibrium}

For a given future path of inflation or nominal interest rates, the equilibrium values of $E_{1}$ and $y_{2}$, are determined by the two equations, (1) at $t=1$ and (5), in which $i_{2}$ is taken as given. In other words, the short-run equilibrium of the model is simply defined by the intersection of the IPLM and W curves. As shown in Figure 4, there are three possible outcomes. Figure 4a shows a 'good' case with high output and a low exchange rate value as the unique equilibrium. Figure $4 \mathrm{~b}$ shows a 'bad' case, where the unexpected currency depreciation is so large that it drives profits and therefore period-2 output to zero. ${ }^{27}$ Finally, Figure $4 \mathrm{c}$ shows an intermediate case with multiple equilibria, where only the two extreme equilibria are stable. We will refer to the stable equilibrium with low output and a depreciated domestic currency (i.e., a high $E_{1}$ at $\left.E^{* *}\right)$ as the "currency crisis" equilibrium.

The reason for multiple equilibria is simple: if a large currency depreciation is expected, consumers will reduce their money demand because expected output is lower. This in turn leads to a currency depreciation, confirming the consumers' expectations. On the other hand, if no large depreciation is expected, it will not occur in equilibrium because in this case domestic consumers will not reduce their demand for the domestic currency.

Sufficient conditions for having a multiplicity of equilibria require the $\mathrm{W}$ curve intersecting the $y_{2}$-axis below the IPLM curve. We thus have:

Proposition 1 A sufficient condition for multiple equilibria including a "currency crisis" equilibrium, is that: $\left(\frac{E_{1}}{P_{1}}\right)_{y_{2}=0, W}<\left(\frac{E_{1}}{P_{1}}\right)_{y_{2}=0, I P L M}$, or equivalently:

$$
\frac{y_{1}-\left(1+r_{0}\right) d_{1}^{c}}{\left(1+i^{*}\right)\left(d_{1}-d_{1}^{c}\right)}<\frac{1+i^{*}}{1+i_{1}} \frac{M_{2}^{s}}{P_{1}} \frac{1}{m^{d}\left(0, i_{2}\right)}
$$

A currency crisis of this type can be set off by a variety of factors. In the case where there are actually multiple equilibria, the crisis could be brought

\footnotetext{
${ }^{27} \mathrm{~A}$ zero level of output is obviously an extreme simplification. In a more general framework, firms would gain competitiveness through a currency depreciation as shown in subsection 3.3. Moreover, output would remain positive for firms without foreign currency debt.
} 
on by pure expectational shift. If everyone believes that there will be crisis, then a crisis occurs. ${ }^{28}$

On the other hand, in the case where the initial configuration is as in Figure 4a, only shocks to fundamentals can bring on a crisis. In this case a small fall in productivity (a shift in the $f(\cdot)$ function) or a slight tightening of the credit market (a shift in $\mu$ ) can shift the $\mathrm{W}$ curve down and shift the economy from a configuration of the kind depicted in Figure 4a, to the one depicted figure 4c. This, in turn, can start off a crisis if people expect the "bad" equilibrium. Such a process is illustrated in Figure 5. The initial equilibrium is at $\left(y^{0}, E^{0}\right)$. The negative shock leads to a currency depreciation, either to $\left(y^{*}, E^{*}\right)$ or in the worst case to $\left(0, E^{* *}\right)$. The latter case corresponds to a currency crisis situation.

Similarly, suppose that, due to a substantial increase in the perceived exchange rate risk the country now has to pay a risk premium on bonds denominated in its currency. In this case the interest-parity equation (1) becomes:

$$
1+i_{t}=\left(1+i^{*}\right) \frac{E_{2}}{E_{1}}+\eta
$$

where $\eta$ is the foreign exchange risk premium after the shock. ${ }^{29}$

This increase in risk shifts the IPLM curve upwards, as the new IPLM equation becomes:

$$
E_{1}=\frac{1+i^{*}}{1+i_{1}} \frac{M_{2}^{s}}{m^{d}\left(y_{2}, i_{2}\right)}+\eta .
$$

Starting from a "good case" situation with only one equilibrium with low $E_{1}$ and high $y_{2}$, this upward shift in IPLM may again lead to a multiple equilibria situation, and therefore to the possibility of a currency crisis. This possibility is actually reinforced by the fact that an increase in the foreign exchange premium raises the interest rate on foreign borrowing which in turn will tend to move the $\mathrm{W}$ curve downward.

Similar effects would also follow from an increase in country risk. This leads to an increase in the interest rates faced by domestic entrepreneurs both with regard to domestic and foreign currency debt obligations. An increase in the country risk premium would thus shift the $\mathrm{W}$ curve downward without

\footnotetext{
${ }^{28}$ It is possible to show that these multiple outcomes can also occur when expectational shifts are taken into account when setting prices (formally, we can show the existence of non-degenerate sunspots equilibria)

${ }^{29}$ In general, the magnitude of the foreign exchange risk premium $\eta$ is likely to increase with transaction costs and market thinness.
} 
affecting the IPLM curve. In Sections 4 and 5 we examine the effects of shocks induced by fiscal and/or monetary policy.

\subsection{A Competitiveness Effect}

Since the output of credit-constrained firms is entirely determined by the supply of credit, our model does not permit a competitiveness effect operating through the usual Keynesian channel. ${ }^{30}$ Here, we sketch an extension of our basic model that allows for competitiveness effect(s) to operate, and examine how our basic analysis would be modified by introducing such effects.

Suppose that an unanticipated shock results in a (short-run) currency depreciation, making domestic goods cheaper than (the same) foreign goods. This competitiveness effect could increase the volume of domestic exports for a same level of investment, provided we allow our entrepreneurs to somehow "work harder". Specifically, assume that entrepreneurs are committed to meet demand at the pre-set price. Therefore when there is an unanticipated shock and domestic goods become cheaper, entrepreneurs have to meet the higher demand. They do so by working harder - which they can always do, but usually prefer not to. Finally assume that when the entrepreneurs have to increase production, some non-contractable aspects of output quality suffer from such an increase in output quantity, and as a result the demand for domestic products, even at the lower price, remains finite. ${ }^{31}$

In this extended model, because the deviation from PPP occurs in period 1 , the output in that period, $y_{1}$, will be an increasing function of $E_{1}$. This implies that an increase in the current nominal exchange rate $E_{1}$ can now have a positive impact on real output $y_{2}$. This, in turn, means that the $\mathrm{W}$ curve is less likely to be downward sloping and may even have slopes of varying sign. ${ }^{32}$ It also implies that output is less likely go to zero as in the benchmark model. ${ }^{33}$

\footnotetext{
${ }^{30}$ See Bernanke, Gertler, and Gilchrist (1999) for a model with both credit constrained and demand constrained firms.

${ }^{31}$ This allows us to maintain ex ante PPP without having domestic demand become infinite when the domestic price falls below the world price.

${ }^{32}$ Krugman (1999b) and Bacchetta (2000) presents examples which incorporates a competitiveness effect.

${ }^{33} \mathrm{~A}$ complete analysis of the extended model with competitiveness effects, would require a careful dynamic specification, since the foreign currency debt effect is likely to be more short-lived than the competitiveness effect.
} 
In particular, when foreign currency debt is low or the credit constraint is not binding, the competitiveness effect will dominate and the $\mathrm{W}$ curve becomes upward sloping. In that case, a currency depreciation is good for firms. Note however that to make a case for a lax monetary stance, we are focusing on economies like the UK in the early 1990s where a currency depreciation increases future output (because the W curve is upward sloping or because credit constraints do not bind). However, this rules out multiple equilibria and currency crises of the kind analyzed above.

\section{The Effect of the Policy Regime}

It is worth pausing at this point and noting that the mechanism generating a currency crisis in this paper departs from most existing models of currency crises, as it relies entirely upon private sector's behavior. By contrast, both the "first generation" and the "second generation" models generate currency crises in the case of a fixed exchange rate economy, based upon expectations about the policy regime. Our analysis so far shows that currency crises may also occur in a (credit-constrained) economy with flexible exchange rates and moreover, does not require us to refer to distortions in government policy.

This does not imply that our approach of currency crises cannot be linked to previous theories: as we shall try to argue in this section, it complements previous explanations, e.g., by Krugman (1979) or Obstfeld (1994). In subsection 4.1, we analyze an explicitly fixed exchange rate regime, while in subsection 4.2 we briefly consider the government's balance sheet constraint and its interaction with private firms.

\subsection{Exchange Rates Regimes}

To illustrate the fact that the specific exchange rate regime is not the most crucial element in the analysis, we now consider the case of an economy with an (initially) fixed exchange rate system. Whilst such a system can maintain a stable exchange rate when the economy is hit by small shocks, the initial exchange rate regime has little influence in preventing a currency crisis following a large shock.

In a fixed exchange rate system, the role of the central bank's international reserves, as well as the rule leading to the abandonment of the fixed rate, need to be specified. Fixing the exchange rate in our model implies a given 
path of money supply in all periods $t>1$, possibly through the use of international reserves; furthermore, it implies that at date $t=1$, the central bank can no longer use the interest rate $i_{1}$ as a policy instrument, if the interest parity condition is to hold perfectly. ${ }^{34}$ More formally, assume that the exchange rate is initially fixed at $E_{t}=\bar{E}$. Then, the PPP and interest parity conditions imply that the monetary equilibrium equation (2) in period 2 can be rewritten as:

$$
M_{2}^{S}=\bar{E} \cdot m^{d}\left(y_{2}, i^{*}\right)
$$

where money supply $M_{2}^{S}$ is now endogenous. On the other hand, equilibrium of the central bank's balance sheet imposes the condition :

$$
M_{2}^{S}=D C_{2}+I R_{2}
$$

where $D C_{2}$ is domestic credit, typically claims on the government, and $I R_{2}$ represents international reserves expressed in domestic currency in period 2 .

To understand why a large real shock may force a government to abandon the fixed exchange rate regime and can precipitate the occurrence of a currency crisis, assume that international reserves cannot fall below some floor level $\overline{I R}$, in line with the first generation literature (e.g., Krugman (1979)); and that $D C_{2}$ is fixed at some level $\overline{D C}$. This situation can be depicted in Figure 6 .

Suppose that initially, before the shock, the economy is in the good equilibrium described by the intersection between the two curves IPLM $M_{0}$ and $W_{0}$ (point A). Then, let $\overline{I P L M}$ denote the lowest IPLM curve consistent with a fixed exchange rate at $E \leq \bar{E}$; this corresponds to a money supply equal to: $M_{2}^{S}=\overline{D C}+\overline{I R}$. Finally, let $B$ denote the point on that curve which corresponds exactly to the nominal exchange rate $\bar{E}$. In other words, the parity $E=\bar{E}$ can be maintained only if output $y_{2}$ is at least equal to its value at point $B .^{35}$

Now, suppose that a large negative productivity or trade shock shifts the $\mathrm{W}$-curve downward (from $W_{0}$ to $W_{1}$ ). Clearly, after the shock it becomes

\footnotetext{
${ }^{34}$ With imperfect substitutability between domestic and foreign assets, the central bank has more flexibility in defending the currency and changing $i_{1}$. For large shocks, however, this does not make the analysis significantly different from the full substitutability case.

${ }^{35}$ Notice that the analysis can also be conducted in terms of the 'shadow' exchange rate as often done in the literature. The intervention of the $\overline{I P L M}$ curve with the $W$ curve gives the shadows exchange rate $\widehat{E}$. As long as $\widehat{E}<\bar{E}$, the fixed exchange rate can be maintained.
} 
impossible to sustain the parity $\bar{E}$ since the $W_{1}$ curve intersects the horizontal line $E=\bar{E}$ to the left of $B$. This implies that the fixed exchange rate $\bar{E}$ has to be abandoned, which in turn may lead the economy to the 'bad' equilibrium $C$ defined by the intersection between $W_{1}$ and $\overline{I P L M}$ in Figure $6 .{ }^{36}$ It is important to note that the decline in reserves that triggers the currency crisis is caused here by the underlying weakness in the financial health of private firms and not by a fiscal deficit as in the first-generation models of currency crises. This does not mean that government behavior and public deficits cannot also have an effect on the occurrence of currency crises, as we will argue argued in the next subsection. Thus, the potential sources of currency crises highlighted in first-generation models, can also be shown to be relevant when analyzed in the context of the "third-generation" model in this paper.

Similarly, we can use our framework to analyze credibility aspects of the kind emphasized by the second generation of currency crises models. For example, instead of assuming a floor level of international reserves, suppose that the government's objective is to minimize a loss function which increases both with the size of output declines and the extent of a currency devaluation. Then, if output depends negatively on the nominal interest rate as will be discussed in Section 5, we can easily re-obtain the multiple equilibrium result of the second generation models. ${ }^{37}$ To see this, note first that an increase in the high interest rate $i_{0}$ reduces output $y_{2}$ and therefore increases the likelihood of a currency depreciation in period 1 . Thus, if at date 0 investors increase their expectation of a currency devaluation in period one, the interest parity condition in period 0 implies that $i_{0}$ must increase, but this in turn will cause an output fall, thereby making the expectation of a currency depreciation self-fulfilling.

Two conclusions can be drawn from these illustrations. First, our model also explains currency crises in economies with an initially fixed exchange rate. Second, first- and second-generation features can interact with the balance sheets of private firms and thereby lead to a currency crisis through the same basic mechanism as above.

What does our model tell us about the optimal exchange rate regime?

\footnotetext{
${ }^{36}$ Note that once the fixed exchange rate is abandoned, the IPLM curve is likely to be shifted by changes in interest rates. A restrictive monetary policy will increase $i_{1}$ and shift IPLM down. However, the IPLM may still shift up thereafter due to an increase in $i_{2}$, which itself is caused by the expectation of a further depreciation (as in Krugman, 1979).

${ }^{37}$ Bensaid and Jeanne (1997) present a reduced-form second-generation model with an explicit cost of high nominal interest rates leading to multiple equilibria.
} 
In the case of large shocks, we have just argued that the outcome is likely to be quite similar under a fixed or a floating exchange rate regime. However, this conclusion would change if a government could credibly commit to never abandon a given exchange rate parity, for example by instituting a currency board or some kind of dollarization policy. Nevertheless, these strategies are not without risks. One potential drawback of maintaining a fixed exchange rate regime over a long period, e.g., through establishing a currency board, is the fact that combined with persistent price rigidity it can lead to currency overvaluation (i.e., to real appreciation, as argued by Calvo and Vegh, 1999)); this, in turn, may further squeeze firms' profits and thereby add to the difficulty of maintaining a fully credible fixed exchange rate policy. Second, a fixed exchange rate may lead to an increase in the proportion of foreign currency debt and therefore to a more negative slope of the $\mathrm{W}$ curve; this, in turn, may add to the difficulty of maintaining a fully credible fixed exchange rate policy. ${ }^{38}$ Finally, full dollarization (i.e., giving up the domestic currency and using the foreign currency for all transactions) would obviously avoid a currency crisis. However, the elimination of crises should be weighted against the potential costs of abandoning the domestic currency. ${ }^{39}$ A full analysis of the costs and benefits of dollarization is left for future research.

\subsection{Public versus Private Debt in Currency Crises}

In the first generation of currency crises models, it is the inconsistency between public sector behavior and a fixed exchange rate that is at the source of a crisis. In this subsection, we emphasize the interaction between fiscal variables and the private sector. This interaction can take two forms. First, a fiscal shock such as an increase in government expenditure or a decline in

\footnotetext{
${ }^{38}$ The impact of the exchange rate regime on the currency composition of debt, however, is still not well understood (see Eichengreen and Hausman, 1999, for a discussion).

${ }^{39}$ For example, suppose that the domestic country is subject to idiosyncratic shocks, or more generally to shocks that are asymmetrically -or at least imperfectly- correlated with shocks in the foreign currency area, and that domestic prices are sticky (e.g. , fixed for two periods or more). Then, not giving up the domestic currency would allow the domestic country to implement countercyclical policies, e.g., to increase $E$ in a fixed exchange rate regime or to reduce $i$ in a flexible exchange rate regime, in order to reduce the real interest rate and/or to increase the real exchange rate and thereby to prevent a big recession following a large negative shock. This is particularly relevant if competitiveness effects of the kind analyzed above, are significant.
} 
tax revenues, may crowd out the private sector and thereby lead to a currency crisis. Second, a negative shock to fundamentals or to expectations may affect both the private and the public sector in such a way that the deterioration of the private sector's financial health is exacerbated by the deterioration of the public budget.

To organize thoughts it is useful to look at a consolidated government's balance sheet. Assume that government activities are such that in each period $t$ we have:

$$
P_{t}\left(g_{t}-t_{t}\right)+\left[x^{G}\left(1+i_{t-1}\right)+\left(1-x^{G}\right)\left(1+i^{*}\right) \frac{E_{t}}{E_{t-1}}\right] P_{t-1} d_{t}^{G}=P_{t} d_{t+1}^{G}+P_{t} s_{t}
$$

where $g_{t}$ and $t_{t}$ denote real expenditure and revenue; $d_{t}^{G}$ is the privately-held public debt contracted in period $t-1$ and due to be reimbursed in period $t ; x^{G}$ denote the fraction of government debt which is in domestic currency; and $s_{t}$ represents real seigniorage revenue. If the exchange rate were fixed, we would also need to add the change in the central bank's international reserves, but for simplicity we only consider the floating exchange rate case in this subsection. If we divide (12) by $P_{t}$ and assume that PPP holds at $t-1$, we get the budget constraint in real terms:

$$
g_{t}-t_{t}+\left[x^{G}\left(1+r_{t-1}\right)+\left(1-x^{G}\right)\left(1+i^{*}\right) \frac{E_{t}}{P_{t}}\right] d_{t}^{G}=d_{t+1}^{G}+s_{t},
$$

The first important point that emerges from equation (13) is that public sector's debt is affected negatively by unanticipated currency depreciations in exactly the same way as private sector's debt. ${ }^{40}$ Thus, it is not difficult to imagine a 'second-generation' model (e.g., in the line of Obstfeld, 1994) where multiple equilibria and the possibility of currency crises, stem from a high proportion of public foreign currency debt. This is in sharp contrast with the existing literature (again, see Obstfeld, 1994) where currency crises occur in economies with high proportions of domestic currency debt and where having foreign currency debt can help avoid a crisis altogether. Behind this contrast lies the fact that previous models would typically assume ex post PPP and no foreign price uncertainty, which implies that foreign currency bonds are a

\footnotetext{
${ }^{40}$ Notice that throughout the paper we consider only short-term (one period) debt. To the extent that the government can have longer maturities that the private sector, it may be less sensitive to exchange rate depreciations.
} 
perfect hedge against currency fluctuations. The experience with countries issuing foreign-currency debt, such as Mexico with its dollar-linked tesobonos, tends to support the view that public foreign currency debt is not always an stabilizing influence.

Let us now turn to the interaction between the private and the public sector. Consider for example an increase in the primary fiscal deficit at time one, $g_{1}-t_{1} \cdot{ }^{41}$ The impact on the private sector depends on which other variable adjusts in (13). First, assume that an increase in the deficit is financed by an increase in seigniorage $s_{1}$. This implies an increase in money growth from period 2 on, which in particular means an increase in $M_{2}^{S}$ and in $i_{2}$ (due to an increase in $\pi_{3}$ ). In our graphical analysis, this implies that the IPLM curve will shift upward, which in turn can push the economy from a 'good' into a 'currency crisis' equilibrium. Interestingly, as in 'first generation' models, the proximate cause of the crisis is a budget deficit financed by future inflation. The mechanism behind the crisis, however, is quite different since it is not the currency attack on the fixed exchange rate, but rather the deteriorating financial health of private firms, which causes the crisis.

Now, suppose that the increased budget deficit leads to a reduction in the amount of lending to firms, through a decline in the credit-multiplier $\mu$. This may be due to some standard crowding out between public and private debt; or because a larger deficit would reduce the amount of government funds available to save insolvent or illiquid banks or firms from bankruptcy. ${ }^{42}$ This decline in $\mu$ will lead to a downward shift of the $\mathrm{W}$ curve, which again may result in the possibility of a crisis. Here again, a negative shock on the public sector leads to a crisis through its impact on private firms.

To summarize our discussion in this section, we have argued that although a currency crisis may be directly triggered by a weakening of private sector firms' balance sheets, it can also be provoked by imbalances in the public sector. This may help explain crises episodes like Brazil in the late 1990s, where the corporate and banking sectors suffered from the increasing fiscal imbalances.

\footnotetext{
${ }^{41}$ This increase could be an exogenous change in fiscal policy or an endogenous decline in tax revenue due to some negative shock affecting domestic output.

${ }^{42}$ Aghion, Bacchetta, and Banerjee (2000b) analyze this case, by introducing commercial banks and their reserve and capital requirements explicitly into the framework.
} 


\section{Monetary Policy}

\subsection{The case for monetary tightening}

The appropriate monetary policy response to the recent crises has been a hotly debated issue. Our model, being an explicitly monetary model, is well suited as a framework for discussing these issues. ${ }^{43}$ Consider the model developed in Sections 2 and 3. Suppose it is known that the economy has a significant chance of switching to the currency crisis equilibrium, either because of a shift in expectations or a because of a real shock. In other words, we are now in a situation such as the one depicted in Figure 4c. Can the monetary authorities do anything that would guarantee that the economy avoids a currency crisis?

Obviously what they need to do is to shift the IPLM curve so that the economy moves to a configuration of the type shown in Figure 4a. Figure 7 shows this case. The correct policy response in this case is obviously to increase the interest rate $i_{1}$ and/or decrease $M_{2}^{S}$ so that the IPLM curve shifts downward. Figure 7 thus shows a situation in which the currency crisis can be avoided and initial output can restored, through appreciating the currency to $E_{1}^{1}$. This can be seen as the standard case for a tight monetary policy during a currency crisis.

The main argument of those defending a lax monetary policy, however, is that interest rate increases negatively affects output. To take this into consideration, we consider a model of the credit market, developed in the Appendix, where credit depends negatively on the real interest rate, i.e., $\mu\left(r_{t}\right)$ with $\mu^{\prime}<0$. To see how this additional effect modifies the $\mathrm{W}$ curve we have to take account of the relationship between the real interest rate and the exchange rate. Using the interest parity condition and the definition of the real interest rate, we have: $1+r_{1}=\left(1+i^{*}\right) P_{1} / E_{1}$. This allows us to rewrite the credit multiplier as $\mu_{t}=\mu\left(E_{1} / P_{1}\right)$, where $\mu^{\prime}>0 .{ }^{44}$ Equation (5)

\footnotetext{
${ }^{43}$ This section summarizes some of the findings of Aghion, Bacchetta, Banerjee (2000b). Notice that we do not examine the interaction between monetary policy and the credibility of the authorities (e.g., see Drazen, 1999, for such an analysis). See Goldfajn and Baig (1998), Goldfajn and Gupta (1999), and Kray (2000) for empirical analyses of this issue and Lahiri and Vegh (2000) and Flood and Jeanne (2000) for other theoretical analyses.

${ }^{44}$ The $\mu$ function is increasing in $E_{1} / P_{1}$, since a high value of $E_{1} / P_{1}$ predicts that future inflation will be high relative to future depreciation, and therefore depresses the real interest rate.
} 
then gets re-expressed in the form:

$$
y_{2}=f\left(\left(1+\mu\left(\frac{E_{1}}{P_{1}}\right)\right)(1-\alpha)\left\{y_{1}-\left(1+r_{0}\right) d_{1}^{c}-\left(1+i^{*}\right) \frac{E_{1}}{P_{1}}\left(d_{1}-d_{1}^{c}\right)\right\}\right) .
$$

Changes in $E_{1}$ (with $P_{1}$ fixed) have now two effects on $y_{2}$. In addition to an increase in the foreign currency debt burden of domestic entrepreneurs, an increase in $E_{1}$ reduces the real interest rate $r_{1}$, which in turn relaxes the credit constraint and therefore increases the availability of funds $d_{2}$ at the beginning of period 2. The slope of the $\mathrm{W}$ curve depends on the relative importance of the two effects. Figure 3, with $\mu$ constant, represents the case where the foreign currency debt effect dominates. In Figure 8 the relationship between $y_{2}$ and $E_{1}$ is positive. It becomes a vertical line at $\widetilde{y}$ when $\mu$ is so large ( $r_{1}$ so small) that the credit constraint is no longer binding. Note that other shapes of the $\mathrm{W}$ curve are possible. In particular, it might be positively sloped for low values of $E_{1}$ and negatively sloped for high values of $E_{1}$.

The exact expression for the slope of the $\mathrm{W}$ curve (from equation (9)) is:

$$
\frac{d\left(E_{1} / P_{1}\right)}{d y_{2}}=f^{\prime}\left(s \Pi_{1}\right) s\left[\frac{\mu^{\prime}}{1+\mu}-\left(1+i^{*}\right)\left(d_{1}-d_{1}^{c}\right)\right]
$$

where $s=(1-\alpha)(1+\mu)$. It is clear from this expression that when there is no foreign currency debt, i.e., when $d_{1}^{c}=d_{1}$, the $\mathrm{W}$ curve is always upwardsloping. As the proportion of foreign currency debt increases, the slope of the $\mathrm{W}$ curve decreases, turning negative; the limit is achieved at $d_{1}^{c}=0$. When credit markets are completely absent, i.e., when $\mu=0$, we must have $d_{1}^{c}=d_{1}=0$ and therefore the $\mathrm{W}$ curve would always be vertical. This is as it should be: when there is no credit, exchange rate variations should not affect investment capacity. The $\mathrm{W}$ curve is also vertical when $\mu$ is very large and therefore the credit constraint is not binding: in this case output should not be affected by the profitability of the firm sector. In the intermediate case where there is a substantial amount of borrowing but the credit constraint still binds, the $\mathrm{W}$ curve can be downward-sloping and relatively flat. ${ }^{45}$ This turns out to be the case where we can have currency crises. In that sense

\footnotetext{
${ }^{45}$ What happens between $\mu=0$ and the non-binding credit constraint is rather complex since each of the terms $f^{\prime}(\cdot), \frac{\mu^{\prime}}{1+\mu}$ and $d_{1}-d^{c}$ depend on the $\mu$ function. In particular, the specific way in which we have modeled the credit market and the decision to borrow in foreign currency plays an important role and for this reason we have chosen not to discuss these aspects in detail.
} 
currency crises will be associated with countries that are at an intermediate level of financial development. ${ }^{46}$

Let us now examine monetary policy where the $\mathrm{W}$ curve slopes up as in Figure 9a. In this case, consider a negative shock that has reduced output from $y^{0}$ to $y^{*}$ and caused a currency depreciation from $E_{1}^{0}$ to $E^{*}$. Then, an expansionary monetary policy, i.e., a decrease in $i_{1}$ or an increase in $M_{2}^{S}$, can help us maintain the initial level of output, $y^{0}$, though such policy will shift the IPLM curve upward and therefore induce a further currency depreciation to $E_{1}^{1}$. Notice, however, that there is no crisis, either potential or actual, in this case. The case where the $\mathrm{W}$ curve slopes down is the same as the one analyzed in Figure 7, so that an interest rate increase can avoid a currency crisis. Finally, there may still be more complex situations where the $\mathrm{W}$ curve has both a positive and a negative slope, as in Figure $9 \mathrm{~b}$. In that case a leftward shift in the $\mathrm{W}$ curve following a negative shock may again lead to multiple equilibria and a potential crisis. While the optimal monetary policy is now restrictive it can only eliminate the risk of a currency crisis at the cost of reducing aggregate output down to $y_{1}^{1}$.

To summarize, as in the extended model with competitiveness effects, an expansionary policy can be justified only in situations where the Wcurve is upward-sloping, i.e., only if currency crises are impossible. The intuition behind this claim is as follows: the effect of lowering nominal interest rates can be beneficial in this model only if lowering nominal interest rates also lowers real interest rates, which in turn raises $\mu$ and has an expansionary effect on output. Now, the only way to lower real interest rates in our model, is to allow the currency to slide down so that the expected future appreciation of the domestic currency can compensate bond holders for the lower interest rate. But allowing the currency to slide in a crisis-prone economy will cause output to contract (this is precisely what makes the economy crisis prone) and this output contraction in turn will lead to further depreciation of the local currency and push the economy closer to a crisis. Therefore a currency crisis in our model demands a tight monetary policy. ${ }^{47}$

\footnotetext{
${ }^{46}$ The connection between financial development and the $\mu$ function is more tightly drawn in the Appendix.

${ }^{47}$ Aghion, Bacchetta, and Banerjee (2000b) analyze the output impact of tight monetary policy in the medium term, i.e., in period 3 .
} 


\subsection{Extensions and generalizations}

\subsubsection{A credit multiplier which depends upon nominal interest rates.}

Our results above rely heavily on the fact that $\mu$ depends only on the real rate of interest and that prices are preset for one period. But one can think of different reasons why it might also depend on the nominal interest rate $i_{1}$. For example, in the case where currency crises are accompanied by banking crises, the government can try to bail out some of the banks by printing money. Failing to do so would contribute to bank failures and bank failures will lead to a reduction in $\mu$. In other words a tight monetary policy will directly lead to a fall in $\mu$. It might also be the case that it takes some time before participants in the bond markets are fully able to adjust to the change in the expected inflation rate that results from changes in $i_{1}$. A credit contraction following an increase in the nominal interest rate $i_{1}$, may also result from the signalling effect of such an increase on a financially fragile economy (e.g. by undermining creditors' confidence in the credit market).

In a model otherwise similar to the one developed above, but with the one difference that the credit multiplier only depends upon the nominal interest rate, Aghion-Bacchetta-Banerjee (2000a) show that: (i) the W-curve is always downward sloping in the space $\left(y_{2}, E_{1}\right)$; (ii) an increase in the period-1 nominal interest rate $i_{1}$ shifts both the IPLM -curve and the $W$-curve downward. In particular, if the credit multiplier $\mu$ is very sensitive to an increase in the nominal interest rate, the W-curve could shift by more than the IPLMcurve, ${ }^{48}$ and as a result, a tight monetary policy (i.e., an increase in $i_{1}$ ) may no longer be the optimal monetary response to the risk of a currency crisis. This model is of course quite extreme since it is only the nominal rate that affects $\mu$. A more reasonable model would have $\mu$ be a function of both the

\footnotetext{
${ }^{48}$ For example, in Aghion-Bacchetta-Banerjee (2000a) where $f(k)=\sigma k$, increasing $i_{1}$ shifts the IPLM- curve downward by more than the W- curve at a given $E_{1}$ if and only if:

$$
-\frac{\mu^{\prime}\left(i_{1}\right) P_{1}\left(y_{1}-\left(1+r_{0}\right) d^{c}-\left(1+i^{*}\right) \frac{E_{1}}{P_{1}}\left(d_{1}-d^{c}\right)\right.}{\left(1+\mu\left(i_{1}\right)\right)\left(1+i^{*}\right)\left(d_{1}-d^{c}\right)}<\frac{E_{1}}{1+i_{1}} .
$$

One can easily see that it is when $\mu^{\prime}\left(i_{1}\right)$ is small in absolute value and/or when the proportion of foreign currency debt $\left(d_{1}-d^{c}\right)$ is large, that this condition is most likely to be satisfied. In that case the above policy conclusion that monetary tightening is the way to avoid a currency crisis, will still apply. However, that conclusion might be reversed if $\mu^{\prime}\left(i_{1}\right)$ turns out to be large in absolute value.
} 
real and the nominal rate. Then, what we just said implies that if the nominal rate effect on $\mu$ is strong enough, a tight monetary policy may not be the right response to a crisis.

\subsubsection{Prolonged Price Stickiness}

Suppose that price stickiness lasts for more than one period. Does this qualify the above policy conclusion that monetary tightening is the optimal response to the risk of a currency crisis?

Consider first the case where the credit multiplier $\mu$ is constant. Then, we know that monetary tightening in period 2 will move the IPLM curve in the $\left(E_{1}, y_{2}\right)$ space downward, thereby avoiding a currency crisis in period 2. But what about period 3? Consider indeed what happens in the twodimensional space $\left(E_{1}, y_{3}\right)$. As we have seen in Section 2 above, $y_{3}$ is an increasing function of $E_{1}$, namely:

$$
y_{3}=f\left((1+\mu)(1-\alpha)\left\{y_{2}-\left(1+i_{1}\right) d_{2}^{c}-\left(1+i^{*}\right) \frac{P_{1}}{E_{1}}\left(d_{2}-d_{2}^{c}\right)\right\}\right),
$$

so that the new $\mathrm{W}$ curve in the space $\left(E_{1}, y_{3}\right)$ is upward sloping. On the other hand, the new IPLM curve in the space $\left(E_{1}, y_{3}\right)$ is either horizontal if $i_{2}$ is fixed, or downward sloping if $i_{2}$ is endogenously determined by money growth targeting (an increase in $y_{3}$ reduces the inflation rate $\pi_{3}$ and therefore also $i_{2}$; furthermore, the IPLM equation implies that $E_{1}$ is an increasing function of $i_{2}$ ). Now, since the $\mathrm{W}$ curve is upward sloping and the IPLM curve is either horizontal or downward sloping in the space $\left(E_{1}, y_{3}\right)$, there cannot be multiple equilibria and therefore currency crises in period 3 when the credit multiplier $\mu$ is constant. Thus, in particular, whilst avoiding a currency crisis in period 2, monetary tightening in period 1 will also avoid such a crisis in subsequent periods.

Consider now the case where $\mu$ depends negatively upon the real interest rate, as derived in the Appendix. Then, if price stickiness extends to period 2 (i.e., $P_{1}=P_{2}$ ), then the multiplier $\mu$ will end up depending directly upon the nominal interest rate $i_{1}$, since increases in $i_{1}$ translates one for one into increases in the real interest rate $r_{1}$ as $1+r_{1}=\left(1+i_{1}\right) P_{1} / P_{2}=1+i_{1}$. In other words, we must simply substitute $\mu\left(i_{1}\right)$ for $\mu\left(r_{1}\right)$ in eq. (14). This means that a tight monetary policy will now shift the $\mathrm{W}$ curve downward in the space $\left(E_{1}, y_{2}\right)$ also in the case where the credit multiplier depends only upon the real interest rate. As we have argued in the previous subsection, 
this in turn will tend to undermine the effects of tight monetary policies in avoiding a currency crisis.

\section{Conclusion}

In this paper we have developed a simple framework to study currency crises and assess the effects of monetary policy. This "third generation" model is particularly well-suited to analyze the case of economies like in Asia, where the source of currency crises lied primarily in the deteriorating balance sheets of private domestic firms and commercial banks rather than in uncontrolled budget deficit policies by local governments (e.g., see Mishkin, 1999).

Five main conclusions emerged from our analysis. First, an economy with a large proportion of foreign currency debt is more likely to face currency crises associated with large recessions and currency devaluations; but the presence of large competitiveness effects will instead decrease the likelihood of a crisis. Second, a currency crisis may occur both under a fixed or a flexible exchange rate regime as the primary source of such a crisis is the deteriorating balance sheet of private firms. Third, public sector imbalances can have destabilizing effects on the domestic currency through the crowdingout effects of public debt (especially public foreign currency debt) on the balance sheet and credit access of private firms. Fourth, unless credit supply does not strongly react to changes in the nominal interest rate, it is always desirable to increase the nominal interest rate if the primary objective is to avoid a currency crisis; this in turn vindicates the IMF approach. This result, however, may cease to apply if credit supply reacts too strongly to changes in the nominal interest rate, for example in the presence of signaling effects or as a result of persistent price rigidity. Fifth, a tight monetary policy will always produce a debt-burden effect on medium-term economic activity.

A natural next step if this framework is to be used for policy purposes, is to empirically assess the relative importance of the various effects pointed out in the paper. In particular, besides the determination of actual foreign currency debt ratios, we need to get a better sense of how credit supply reacts in practice to changes in the real or the nominal interest rate; we also need to assess the elasticities of money demand with respect to income and to the nominal interest rate. For example, our analysis indicates that monetary tightening should be used to avoid a currency crisis if the credit multiplier does not react too strongly to changes in the nominal interest rate that leave 
the real interest rate unchanged. We thus need to understand the actual behavior of this multiplier before drawing definite policy conclusions. Our prior at this stage - but again this requires further empirical investigation is that the credit multiplier should not dramatically respond to changes in the nominal interest rate alone, at least insofar as those changes are not too dramatic and/or interest rate increases are accompanied by complementary policies aimed at maintaining the credit multiplier, in particular adequate government support to banks and bank restructuring. Finally, we need to evaluate the relative speeds of price versus interest rate adjustments as our analysis suggests that the optimal design of monetary policy, is potentially sensitive to the degree of price stickiness, or more precisely to the duration of the deviation from PPP following the initial shock. 


\section{References}

[1] Aghion, Ph., Ph. Bacchetta, and A. Banerjee (1999a), "Financial Liberalization and Volatility in Emerging Market Economies," in P.R. Agénor, M. Miller, D. Vines, and A. Weber (eds.), The Asian Financial Crises: Causes, Contagion and Consequences, Cambridge University Press, p. 167-190. Published under the wrong title "Capital Markets and the Instability of Open Economies".

[2] Aghion, Ph., Ph. Bacchetta, and A. Banerjee (1999b), "Capital Markets and the Instability of Open Economies," CEPR Discussion Paper No. 2083.

[3] Aghion, Ph., Ph. Bacchetta, and A. Banerjee (2000a), "A Simple Model of Monetary Policy and Currency Crises," European Economic Review 44, 728-738.

[4] Aghion, Ph., Ph. Bacchetta, and A. Banerjee (2000b), "A Corporate Balance-Sheet Approach to Currency Crises," in progress.

[5] Aghion, Ph., A. Banerjee, and T. Piketty (1999), "Dualism and Macroeconomic Volatility," Quarterly Journal of Economics.

[6] Bacchetta, Ph. (2000), "Monetary Policy with Foreign Currency Debt," Study Center Gerzensee Working Paper No. 00.03.

[7] Bernanke, B. and M. Gertler (1989), "Agency Costs, Net Worth, and Business Fluctuations," American Economic Review 79, 14-31.

[8] Bernanke, B. and M. Gertler (1995), "Inside the Black Box: The Credit Channel of Monetary Policy Transmission," Journal of Economic Perspectives, Vol. 9, 27-48.

[9] Bernanke, B., M. Gertler, and S. Gilchrist (1999), "The Financial Accelerator in a Quantitative Business Cycle Framework," in J. Taylor and M. Woodford (eds), Handbook of Macroeconomics, vol. 1C, 1341-1393.

[10] Blanchard, O.J. (1996), Macroeconomics, Prentice Hall.

[11] Bohn, H. (1990), "A Positive Theory of Foreign Currency Debt," Journal of International Economics 29, 273-292. 
[12] Burnside, C., M. Eichenbaum, and S. Rebelo (2000), "Hedging and Financial Fragility in Fixed Exchange Rate Regimes," paper presented at ISOM, Helsinki.

[13] Calvo, G.A. (1998), "Balance of Payments Crises in Emerging Markets: Large Capital Inflows and Sovereign Governments," Paper presented at the NBER Conference on Currency Crises, Cambridge, Mass., February 1998.

[14] Calvo, G. and C. Vegh (1998), "Inflation Stabilization and BOP Crises in Developing Countries," in J. Taylor and M. Woodford (eds), Handbook of Macroeconomics, vol. 1C, 1531-1614.

[15] Cooper, R. (1971) "Currency Devaluation in Developing Countries," Princeton's Essays in International Finance, reproduced in P.B. Kenen (ed.), The International Monetary System: Highlights from Fifty Years of Princeton's Essays in International Finance, Boulder and Oxford:Westview Press.

[16] Corsetti, G., C. Pesenti and N. Roubini (1998), "What Causes The Asian Currency and Financial Crisis? Part I: A Macroeconomic Overview," NBER Working Paper 6833, December.

[17] Drazen, A. (1999), "Interest Rate Defense Against Speculative Attacks Under Asymmetric Information," mimeo.

[18] Eichengreen, B. and R. Hausmann (1999), "Exchange Rate and Financial Fragility," paper presented at the Federal Reserve Bank of Kansas City's Conference on Issues in Monetary Policy, August.

[19] Engel, C. (1993), "Real Exchange Rates and Relative Prices: An Empirical Investigation," Journal of Monetary Economics 32, 35-50.

[20] Falcetti, E. and A. Missale (1999), "The Currency Denomination of Public Debt and the Choice of the Monetary Regime," mimeo.

[21] Flood, R. and N. Marion (1999), "Perspectives on the Recent Currency Crises Literature," International Journal of Finance and Economics 4, $1-26$. 
[22] Flood, R.P. and O. Jeanne (2000), "An Interest Rate Defense of a Fixed Exchange Rate?" mimeo, IMF.

[23] Furman, J. and J.E. Stiglitz (1998), "Economic Crises: Evidence and Insights from East Asia," Brooking Papers on Economic Activity 2, 1135.

[24] Garber, P. and Svensson LE..(1995), "The Operation and Collapse of Fixed Exchange Rate Regimes," Handbook of International Economics, Vol.3.

[25] Goldfajn, I. and T. Baig (1998), "Monetary Policy in the Aftermath of Currency Crises: The case of Asia," IMF Working Paper, WP/98/170, December.

[26] Goldfajn, I. and P. Gupta (1999), "Does Monetary Policy Stabilize the Exchange Rate Following a Currency Crisis?", IMF Working Paper, WP/99/42, March.

[27] Jeanne, O. (2000a), "Foreign Currency Debt and the Global Financial Architecture," European Economic Review 44, 719-727.

[28] Jeanne, O. (2000b), Currency Crises: A Perspective on Recent Theoretical Developments, Special Papers in International Economics No. 20, International Finance Section, Princeton University.

[29] Kray, A. (2000), "Do High Interest Rates Defend Currencies during Speculative Attacks?" mimeo, World Bank.

[30] Krugman, P. (1979), "A Model of Balance of Payments Crises," Journal of Money Credit and Banking 11, 311-325.

[31] Krugman, P. (1999a), "Balance Sheets, The Transfer Problem, and Financial Crises," in P. Isard, A. Razin, and A. Rose (eds.), International Finance and Financial Crises, Essays in Honor of Robert P. Flood, Kluwer, Dordrecht.

[32] Krugman, P. (1999b), "Analytical Afterthoughts on the Asian Crisis," mimeo, MIT.

[33] Krugman, P.R. and M. Obstfeld (2000), International Economics - Theory and Policy, Addison-Wesley. 
[34] Lahiri, A. and C.A. Végh (2000), "Output Costs, BOP Crises, and Optimal Interest Rate Policy," mimeo, Department of Economics UCLA.

[35] Mishkin, F.S. (1996), "Understanding Financial Crises: A Developing Country Perspective," Annual World Bank Conference on Development Economics, 29-62.

[36] Mishkin, F.S. (1999), "Global Financial Instability : Framework, Events, Issues," Journal of Economic Perspectives 13, 3-20.

[37] Obstfeld, M. (1994), "The Logic of Currency Crises," Cahiers Economiques et Monétaires, Banque de France, 43, 189-213.

[38] Obstfeld, M. and K. Rogoff (1995), "Exchange Rate Dynamics Redux," Journal of Political Economy 103, 624-60.

[39] Obstfeld, M. and K. Rogoff (1996), Foundations of International Macroeconomics, MIT Press.

[40] Radelet, S. and J. Sachs (1998), "The Onset of the East Asian Financial Crisis," NBER Working Paper No. 6680.

[41] Stiglitz, J.E. (1998), "Knowledge for Development: Economic Science, Economic Policy, and Economic Advice," Annual World Bank Conference on Development Economics, 9-58. 


\section{A Appendix: The Credit Multiplier}

The credit multiplier $\mu_{t}$ is derived, as in Aghion-Bacchetta-Banerjee (1999b), from ex post moral hazard considerations. Namely, suppose that domestic entrepreneurs can either produce transparently and fully repay their loan or instead can hide their production in order to default on their debt repayment obligations. There is a nominal cost to hiding, which is proportional to the amount of funds invested: $c P_{t} k_{t}$. Yet, whenever the entrepreneur chooses to default, the lender can still collect his due repayment with probability $p$. Thus, the borrower will decide not to default if and only if:

$$
P_{t} y_{t}-\left(1+i_{t-1}\right) P_{t-1} d_{t} \geq P_{t} y_{t}-c P_{t} k_{t}-p\left(1+i_{t-1}\right) P_{t-1} d_{t},
$$

where the LHS (resp. RHS) is the borrower's net expected revenue if she repays (resp. if she defaults on) her debt. Then, the above incentive constraint can be rewritten as: $d_{t} \leq \mu_{t} w_{t}$, where:

$$
\mu_{t}=\mu\left(r_{t-1}\right)=c /\left[(1-p)\left(1+r_{t-1}\right)-c\right]
$$

The multiplier $\mu_{t}$ is increasing in the monitoring probability $p$ (which in turn reflects the level of financial development of the economy) and it is decreasing in the real interest rate $r_{t-1}$. The currency composition of debt does not affect $\mu_{t}$ since lending is determined before any shock occurs, that is at a time where both the PPP and the interest parity conditions hold. 


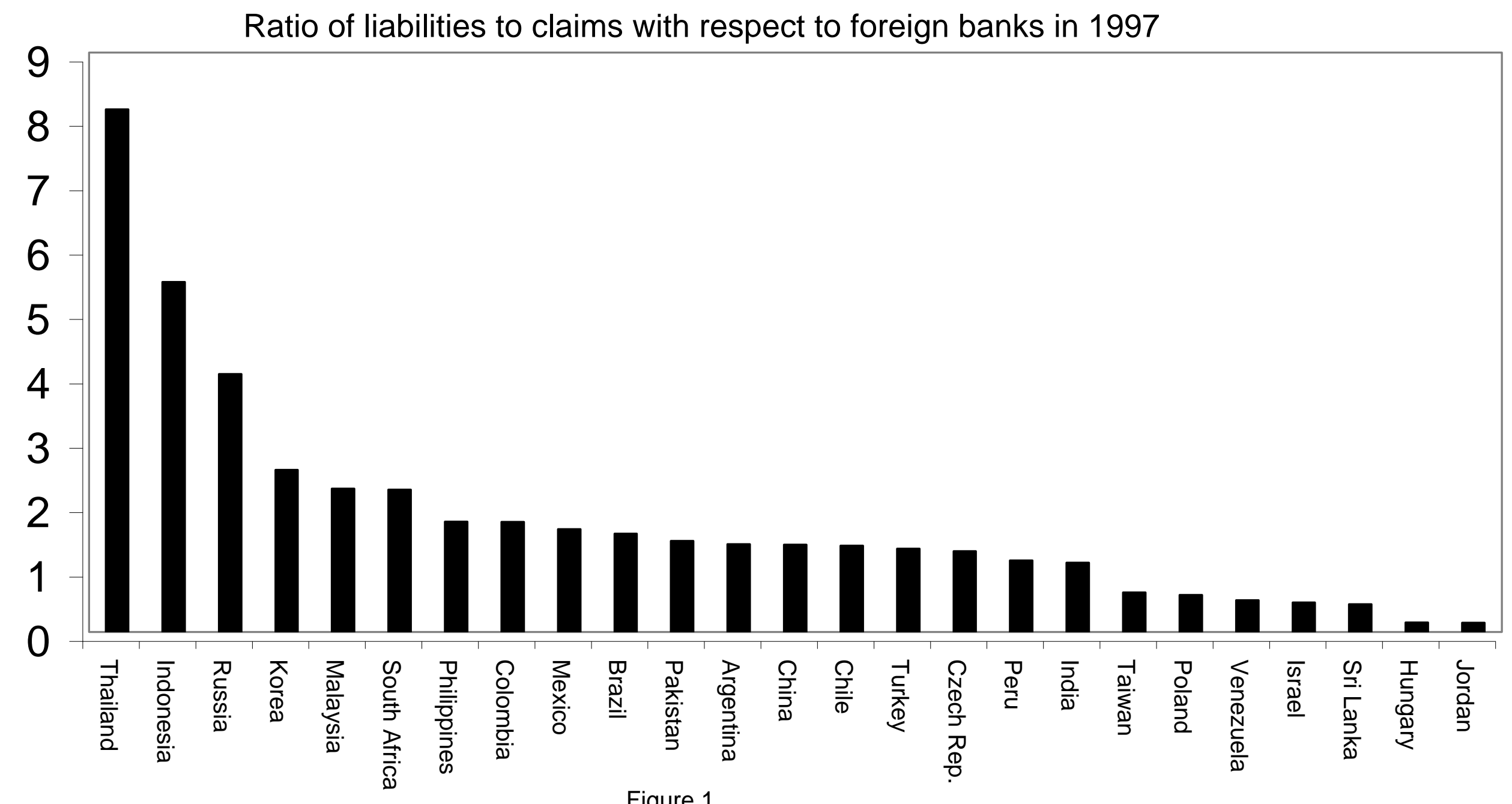

Source: Joint BIS-IMF-OECD-World Bank statistics on external debt.

The ratio is computed as line $\mathrm{J}$ divided by line $\mathrm{M}$. 


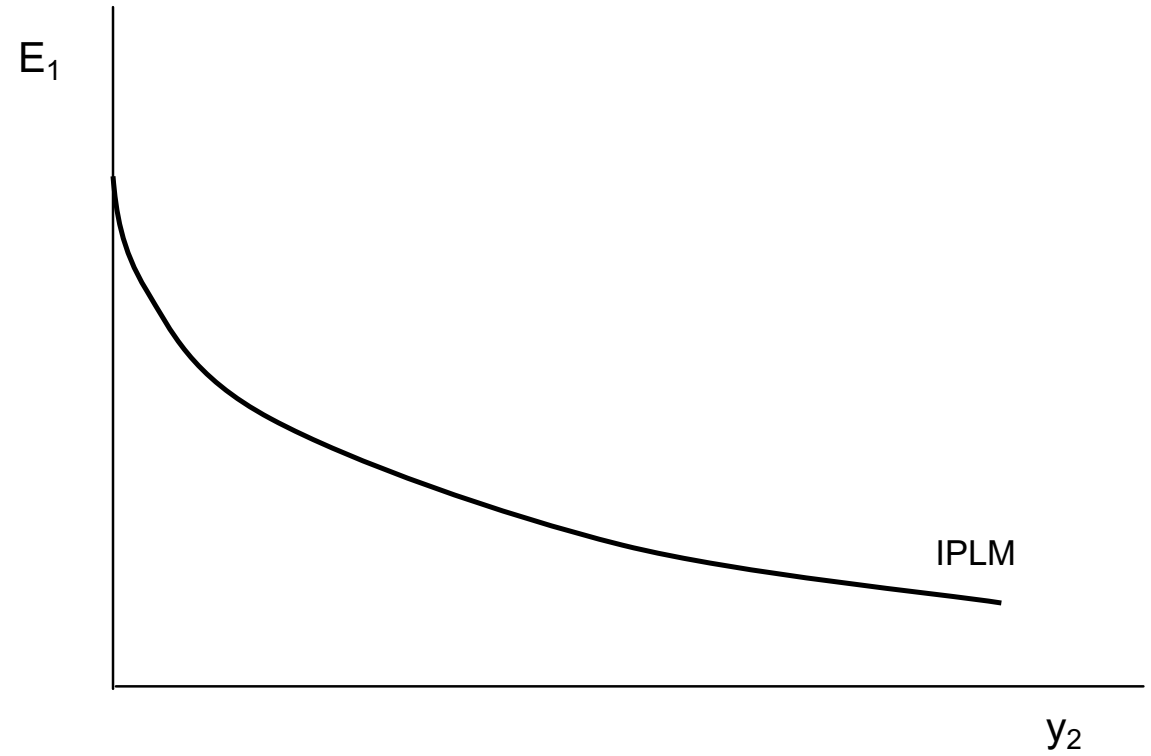

Figure 2

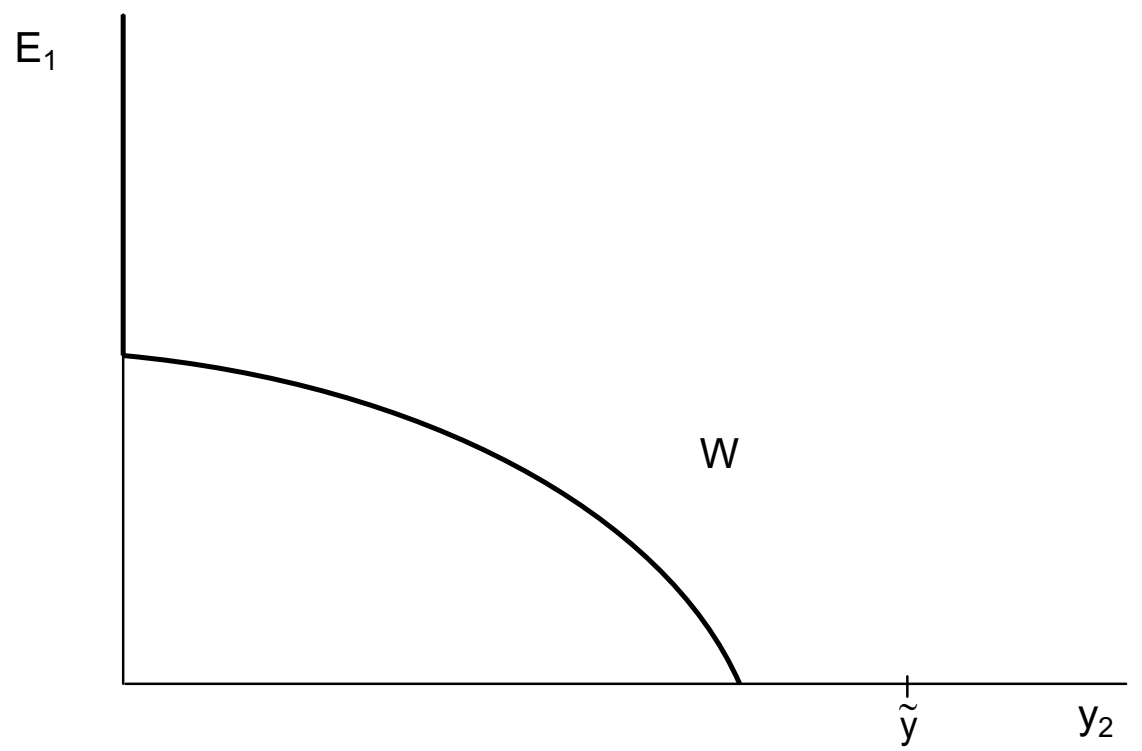

Figure 3 


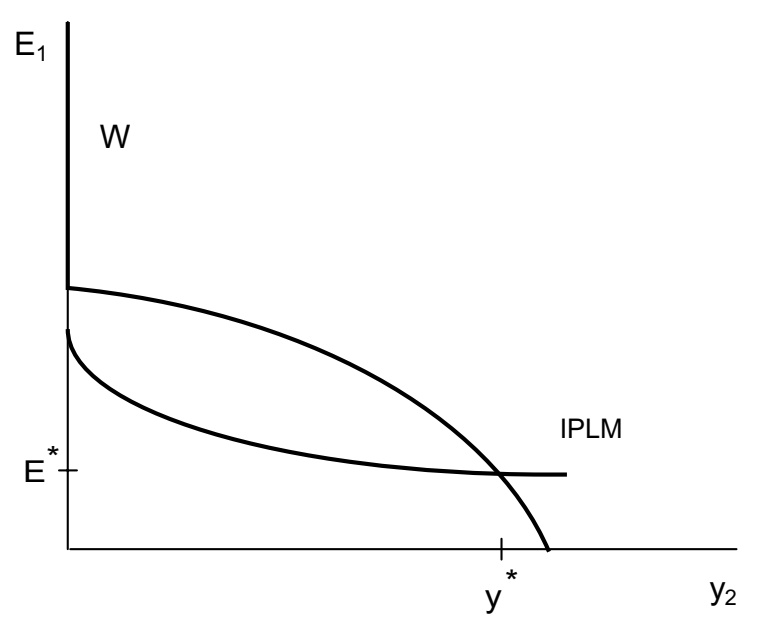

Figure 4a

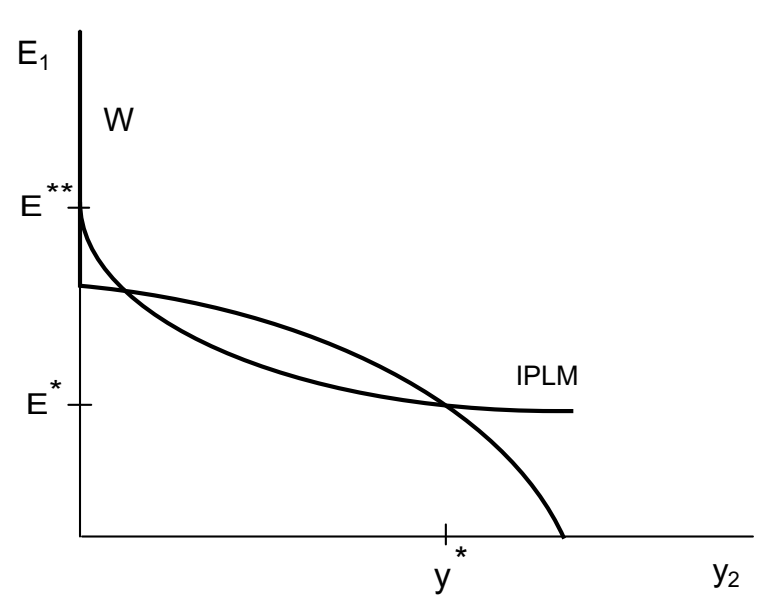

Figure 4c

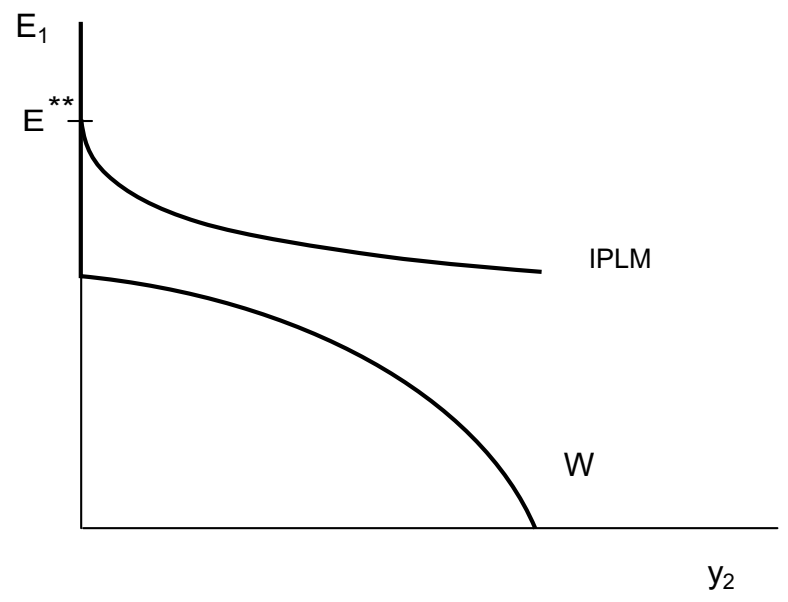

Figure $4 b$ 


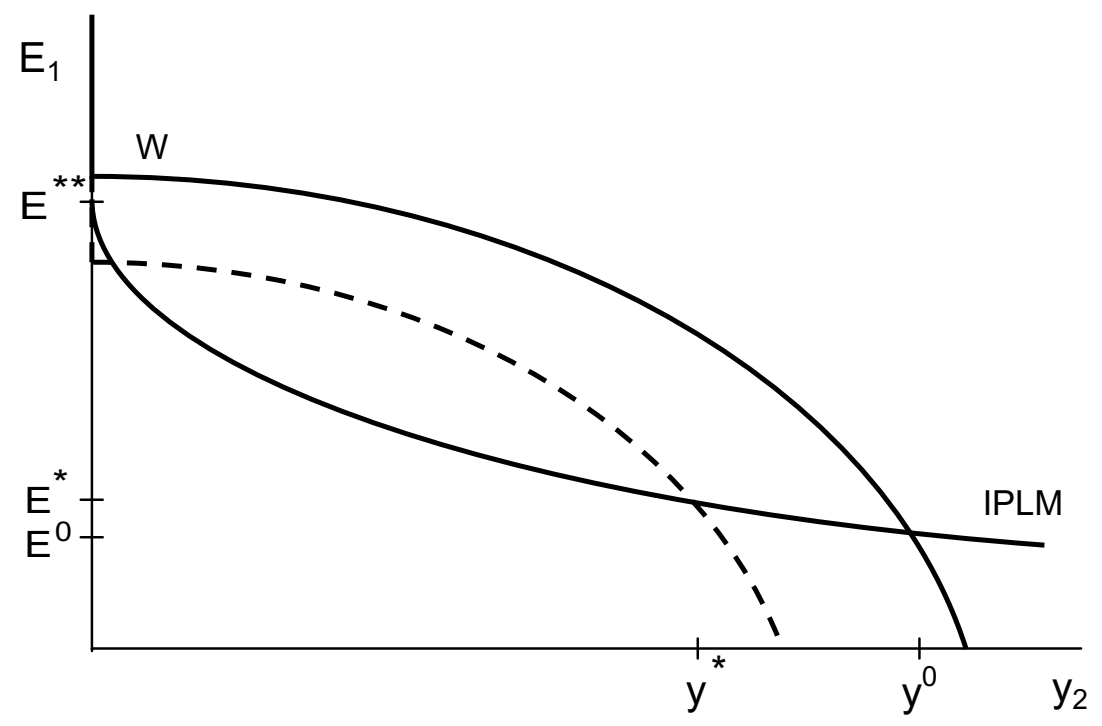

Figure 5 


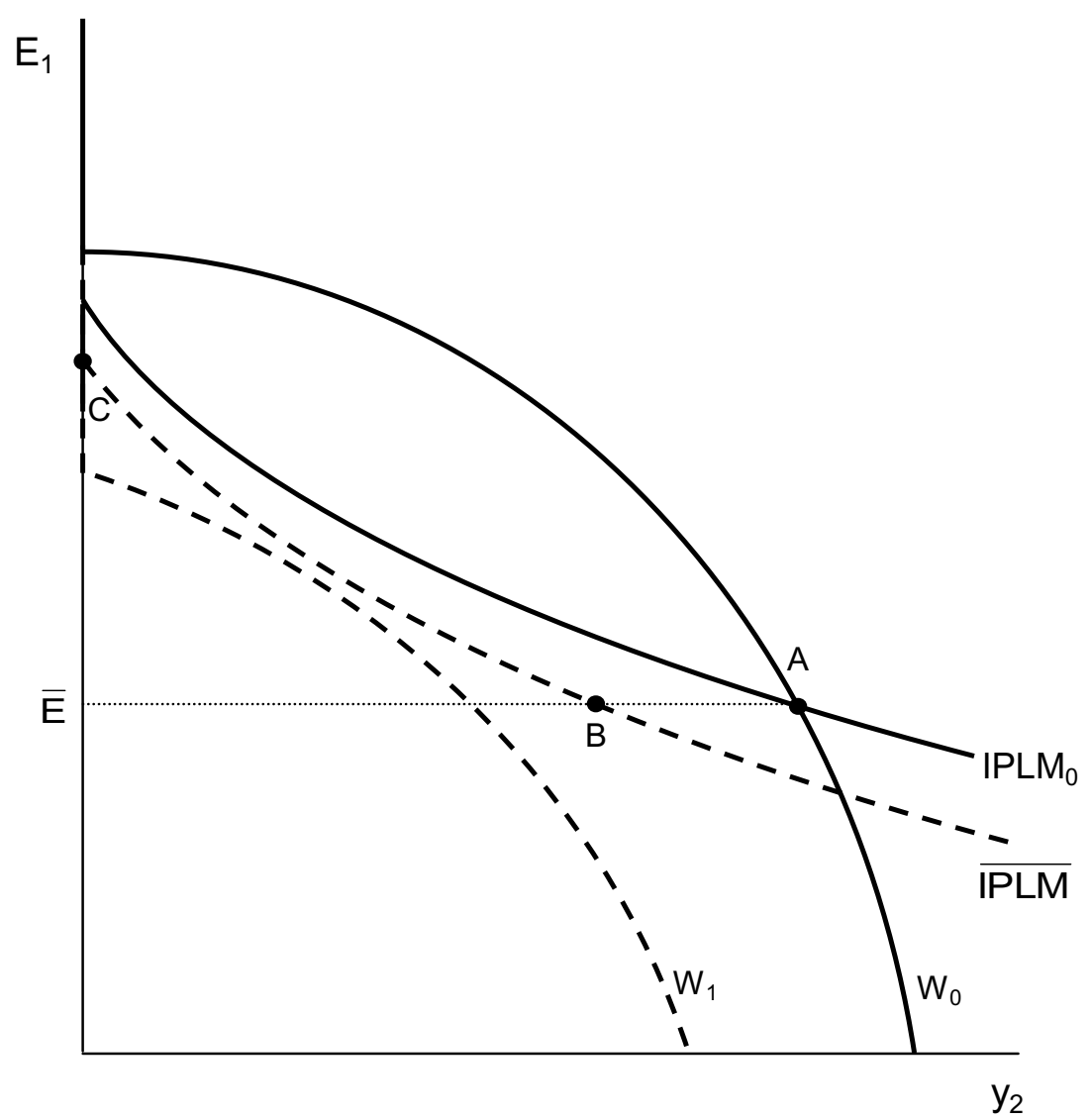

Figure 6 


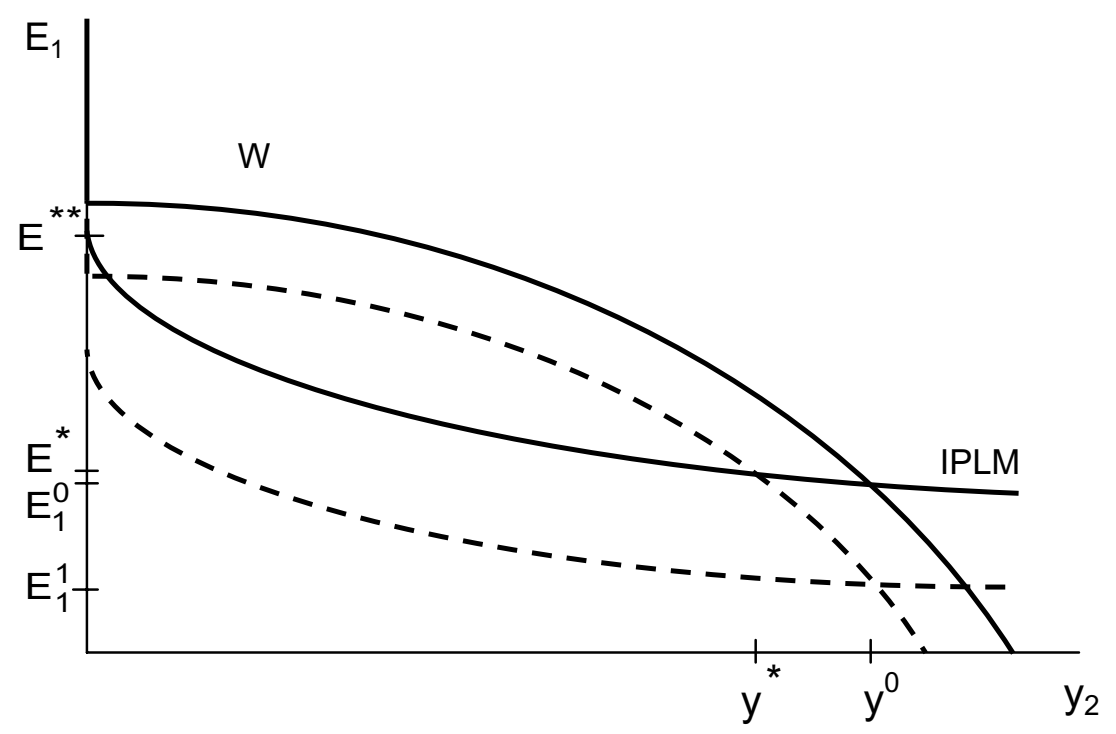

Figure 7 


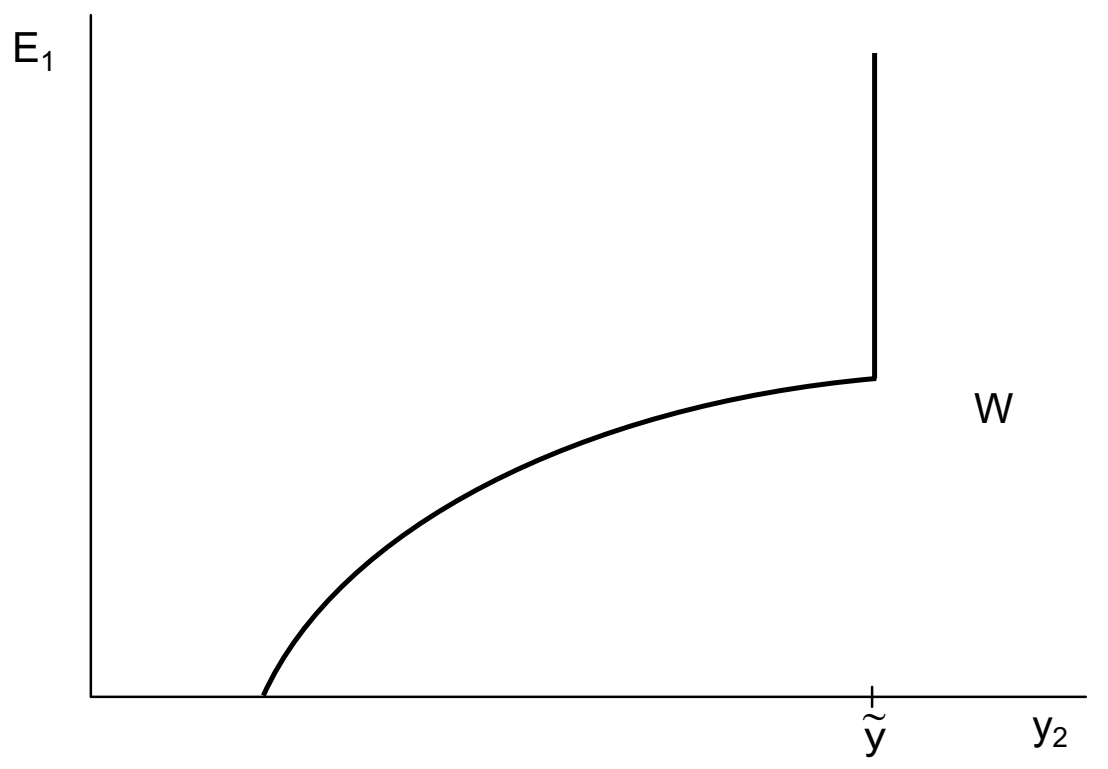

Figure 8 


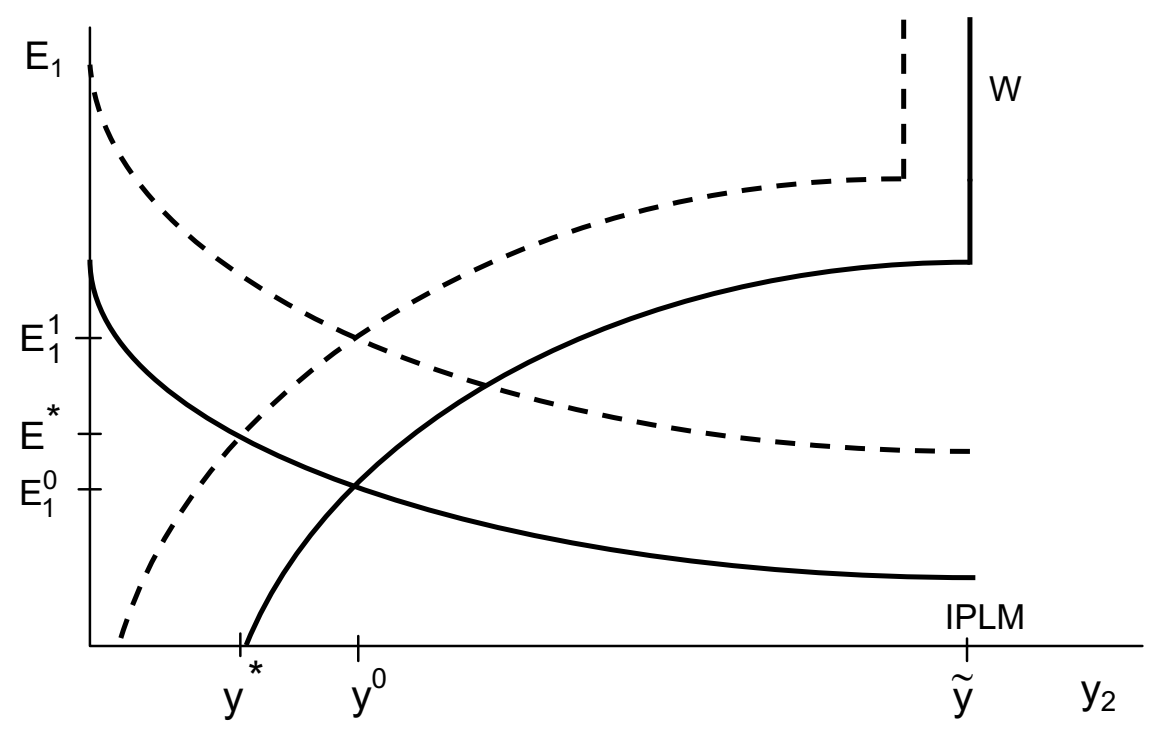

Figure 9a

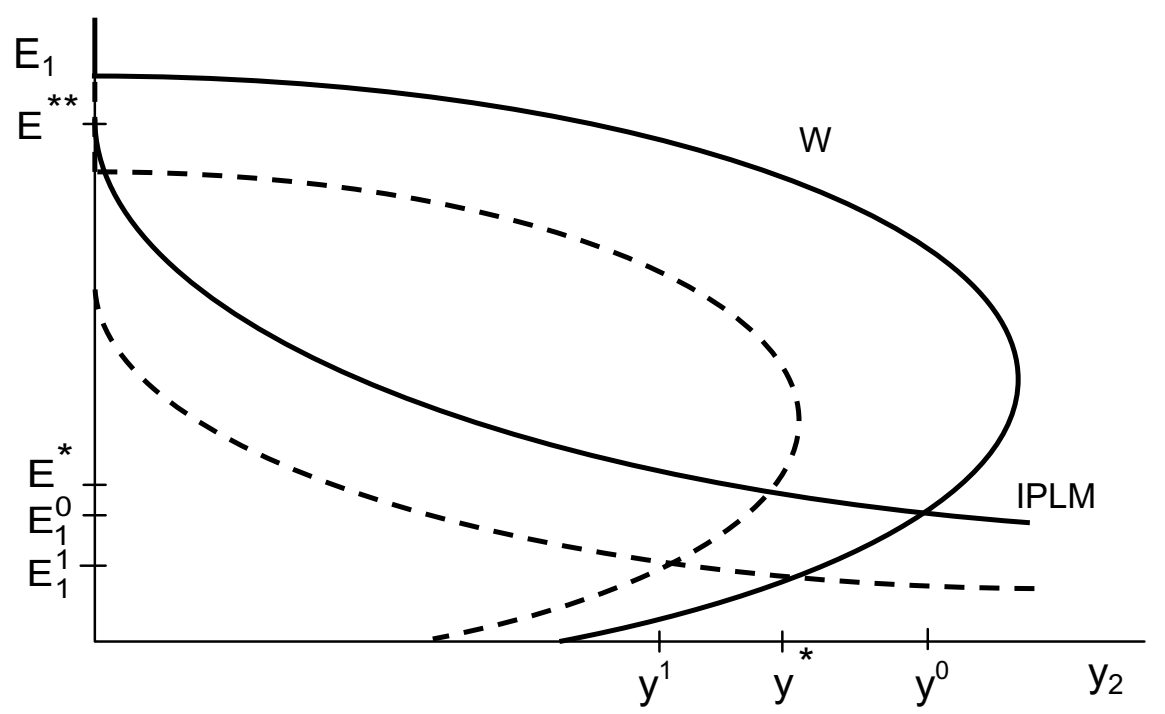

Figure 9b 